\title{
Towards a Socio-Economic Model for Southwest Asian Cereal Domestication
}

\author{
Alexander Weide
}

Citation: Weide, A. Towards a Socio-Economic Model for Southwest Asian Cereal Domestication. Agronomy 2021, 11, 2432. https:// doi.org/10.3390/agronomy11122432

Academic Editors: Valentina Caracuta, Roberto Papa and Ferran Antolin

Received: 20 October 2021

Accepted: 24 November 2021

Published: 29 November 2021

Publisher's Note: MDPI stays neutral with regard to jurisdictional claims in published maps and institutional affiliations.

Copyright: (C) 2021 by the author. Licensee MDPI, Basel, Switzerland. This article is an open access article distributed under the terms and conditions of the Creative Commons Attribution (CC BY) license (https:/ / creativecommons.org/licenses/by/ $4.0 /)$.
School of Archaeology, University of Oxford, Oxford OX1 3TG, UK; alexander.weide@arch.ox.ac.uk

\begin{abstract}
Mechanisms of selection for domestication traits in cereals and other annual plants are commonly explained from agro-technological and genetic perspectives. Since archaeobotanical data showed that domestication processes were slow and protracted, research focused on genetic constraints and hypothetical 'non-selective' management regimes to explain the low selection rates. I argue that these factors only partially explain the observed patterns and develop a model that contextualises the archaeobotanical data in their socio-economic settings. I propose that developments towards individual storage by small household units and the gradual increase in storage capacities with the development of extended households represent key factors for establishing the conditions for selection, as these practices isolated individually managed and stored cereal subpopulations and gradually reduced the need to replenish grain stocks with grains from unmanaged populations. This genetic isolation resulted in stronger and more persistent selection rates and facilitated the genetic fixation of domestication traits on a population level. Moreover, individual storage facilities within buildings reflect gradual developments towards households as the social units that mobilised agricultural labour, which negotiated new sharing principles over cultivated resources and drove the intensification of cultivation practices. In this sense, selection rates and the slow domestication process can be understood as a function of limited food sharing networks and increased labourinputs into early arable environments-socio-economic processes that also unfolded gradually over a protracted period of time.
\end{abstract}

Keywords: cultivation; non-shattering ears; selection rates; households; storage; food sharing; labour

\section{Introduction}

The domestication of cereals in southwest Asia is one of the best-documented domestication processes worldwide. Evidence for the systematic harvesting and processing of wild cereals dates back to ca. 23,000 years at Ohalo II at the Sea of Galilee, while a strong focus on the large-scale exploitation of cereals developed at the transition to the early Holocene and the appearance of increasingly sedentary communities during the Pre-Pottery Neolithic (PPN) (Table 1; Figure 1) [1-3]. Increased grain size is one key domestication trait in seed crops and enlarged cereal grains appeared during the second half of the 12th millennium $\mathrm{BP}$ [4-8]. Whether these early records for larger grains relate to selection or are an effect of changing climatic conditions and $\mathrm{CO}_{2}$ levels is, however, not fully clear [9]. In cereal chaff assemblages that date to around ca. 10,500 cal. BP, morphological changes are detectable that relate to the development of non-shattering ears, a key domestication trait that prevents the ripe ears to shatter upon maturity [10-12]. Both traits continued to develop over the next ca. 1000-2000 years before the first fully non-shattering cereal populations with profoundly enlarged grains were established and are visible in the archaeobotanical record $[6,10,11,13]$. The documentation of this protracted process revolutionised thinking about domestication as an evolutionary process because it was widely accepted previously that key domestication traits like non-shattering ears can be selected for within less than 200 years, even under conditions of unconscious selection [14]. 
Table 1. Chronology of the Pre-Pottery Neolithic (PPN). Dates based on [15,16].

\begin{tabular}{cc}
\hline Period & Absolute Dates (cal. BP) \\
\hline PPNA & $11,700-10,700$ \\
early PPNB & $10,700-10,200$ \\
middle PPNB & $10,200-9500$ \\
late PPNB & $9500-8700$ \\
\hline
\end{tabular}

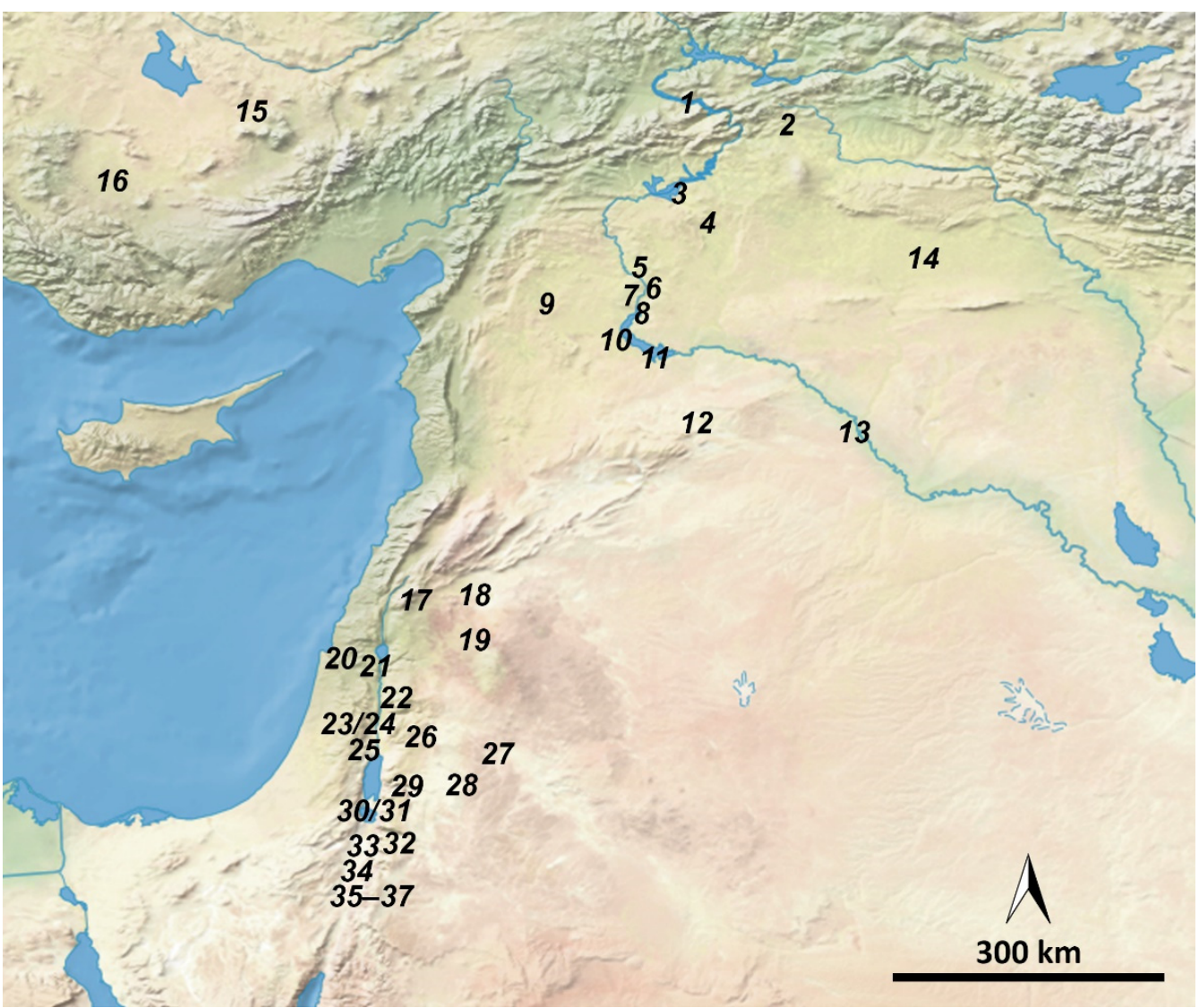

Figure 1. Distribution of PPN sites mentioned in the text. Key to sites: (1) Cafer Höyük, (2) Çayönü, (3) Nevalı Çorı, (4) Göbekli Tepe, (5) Tell 'Abr III, (6) Dja'de, (7) Tell Halula, (8) Jerf el Ahmar, (9) Tell Qaramel, (10) Tell Mureybet, (11) Tell Abu Hureyra, (12) El Kowm 2, (13) Tell Bouqras, (14) Seker al-Aheimar, (15) Aşiklı Höyük, (16) Çatalhöyük, (17) Tell Ramad, (18) Tell Aswad, (19) Tell Qarassa North, (20) Yiftahel, (21) Ohalo II, (22) Iraq ed-Dubb, (23) Gilgal I, (24) Netiv Hagdud, (25) Jericho, (26) 'Ain Ghazal, (27) Azraq basin, (28) Wadi el-Jilat, (29) Es-Sifyia, (30) Dhra', (31) ZAD 2, (32) el-Hemmeh, (33) Wadi Fidan, (34) Wadi Faynan, (35) Beidha, (36) Basta, (37) Ba'ja.

Purugganan and Fuller $[17,18]$ calculated selection rates based on the proportions of non-shattering spikelets among PPN cereal chaff assemblages over time and found that rates were significantly lower than those suggested by experimental studies [14]. Which factors caused this slow development? Most authors hypothesised that PPN cultivation regimes and harvesting techniques did not induce strong selection for traits such as nonshattering, for example when harvesters targeted shattering spikelets by beating them into baskets and ground collecting, or alternatively when ears are harvested in a green state before they shatter $[6,10,14,19,20]$. These explanations focus on scenarios where selection for non-shattering induced by early cultivators would be very weak or absent. However, except for harvesting large proportions of semi-ripe ears with sickles, most of the agro-technological aspects of non-selective management regimes cannot be examined directly from archaeological data and remain hypothetical. Others suggested that the complex genetic basis for key domestication traits should have played a key role in the 
slow selection processes [17], which genetic studies and modelling of genetic selection under low selection rates generally support (e.g., Allaby et al. [21] and Avni et al. [22]). Finally, continuous gene flow between cultivated and uncultivated populations features as a central assumption for why genetic selection was weak, as most early arable fields were situated in the distribution area of the crop progenitors and poor harvests would likely have urged early farmers to replenish seed stocks from wild stands $[10,23]$. The slow domestication process in southwest Asia-but also other world regions-is therefore predominantly explained with a focus on mechanisms that directly affect selection. These include hypothetical combinations of non-selective management practices, gene flow between populations that experience different selection pressures, and genetic constraints on the selection of domestication traits $[13,24,25]$.

A problem with the protracted domestication model and the hypotheses surrounding slow selection is that researchers hardly relate them to the archaeological record and specific contexts from which the data derive. As a result, discussions focus on the direct effects and genetic constraints of selection but not on the processes that establish the conditions for selection. Asouti and Fuller [26] provided an extensive review of emerging plant management practices in their socio-cultural contexts in southwest Asia but focused on the earlier stage of the PPN, the PPNA, while not discussing the PPNB when domestication traits become visible in the archaeobotanical record. It is, however, during the PPNB when we see developments in architecture and artefact assemblages that signal substantial changes in the social and economic organisation of the communities that created the arable environments in which selection for domestication traits unfolded. These developments include the appearance of rectangular and multi-roomed architectural structures with internal storage features, which are widely interpreted as residential units of households that changed the way food resources were exploited, stored, and distributed within PPN communities [15,27-36].

\section{Households in the Pre-Pottery Neolithic}

Households, in the broadest sense, represent the smallest socio-economic units of agricultural communities, which are socially and symbolically constructed, and together engage in economic activities [37,38]. Archaeologists often adopt a functional definition of households that is oriented on the economic tasks and consumption practices shared between all household members $[37,39,40]$. This approach is applicable to archaeological data, focusing on residential buildings and the associated structures and artefacts. However, it is well recognised that household membership is variable and not fully reflected in the architectural and artefactual record [37,38,40-43]. A major concern in household archaeology, therefore, is to understand the size and social organisation of households. The members of one household can live in separate buildings and household membership often crosscuts kinship lines, while extended households may encompass several smaller social units that pool labour and resources $[37,40,43,44]$. This variability complicates a correlation of single archaeological structures with households as social units, which is why most archaeologists adopted the functional definition of households as task-oriented groups that together engage in economic activities, including, but not limited to, crop cultivation, storage, processing, and consumption [29,32,34,37-40]. I also follow this definition, because, as will be argued, the practical organisation of food storage and agricultural labour is most critical to understand changing selection rates for plant domestication traits.

Discussions of developing household organisation throughout the PPN in southwest Asia focus on their size and social composition, economic autonomy, and the development of private property over material goods and food resources. PPNA household organisation is debated, and discussions focused on a distinction between loose household groups whose members inhabited several small buildings [31,44], and nuclear family households, thought of as spouses and their children, that each lived in one residential structure [40]. There is more agreement that by the middle PPNB, communities in the southern Levant and along the middle Euphrates were organised in small co-residential 
units, perhaps nuclear family households, which inhabited larger, commonly rectangular buildings $[27,29,31,32,35,40,45,46]$. This reconstruction is mainly based on the standardised size and layout of buildings at many middle PPNB sites, which contain individual food storage, processing, and consumption installations. Other researchers were more cautious in associating households with specific kinship groups such as nuclear families, as household membership during the PPN may have been constructed symbolically $[36,38,42,43]$. Yaka et al. [47] recently showed that genetic relationships between individuals buried in the same buildings at central Anatolian Neolithic sites varied geographically and changed through time, which reinforces that PPN households were also symbolically constructed and crosscut kinship lines. Developments towards the late PPNB between the southern Levant and southeast Anatolia are commonly understood as the emergence of extended households, where several smaller social units closely cooperate in agricultural tasks, pool labour and resources, and may even share storage facilities and agricultural products $[27,29-33,35,36,40,45,46,48-50]$.

The idea of private ownership over cultivated and individually stored food resources, and by extension over arable land, shaped many discussions around the changing economic organisation of PPN households [27,29,31,33,34,40,44,46]. Bowles and Choi [51,52] formalised this idea and developed an economic model for the adoption of cultivation in southwest Asia, which is centred on the expectation that members of a community where food is widely shared have no incentive to invest in labour-intensive activities related to plant cultivation, as they would have to share the outputs and could not benefit from their labour investments $[44,53,54]$. Only the negotiation of new ownership rights over cultivated foods, centred on the decision with whom to share, would have established a lasting incentive to invest more labour into plant cultivation. The relocation of storage facilities into buildings during the early and middle PPNB throughout southwest Asia is commonly taken as an argument for changing notions of ownership and emerging private property over the resources cultivated by one household [52]. To which degree intramural storage facilities reflect the idea of private property is, however, unclear, and Kuijt [55] argued that a change in the location of food storage is also related to better control of humidity, pests, and general oversight of stored foods. As will be discussed in greater detail below, the movement of storage facilities into buildings during the early and middle PPNB coincided with a general development where plant processing and food preparation facilities also became associated with individual residential units. This development reflects a general trend towards a 'privatisation' of household life and the gradual restriction of food sharing networks, related to the expectation that individual households organised their own agricultural production, including food storage and the mobilisation of agricultural labour [30,33,40].

In this context, Bogaard [50] drew attention to the important role of supra-household cooperation in farming communities. She questions whether households during the PPN were ever fully autonomous and self-sufficient, as resilient agricultural systems normally rely on various degrees of cooperation. Different forms of supra-household cooperation represent a form of collective risk management and may involve the communally negotiated allocation of arable land to households or pooling of resources for labour-intensive tasks such as post-harvest crop processing. Although the archaeological correlates of supra-household cooperation cannot be investigated at many sites, for example due to limited exposures or the absence of adequate in-situ contexts, the integration of individual households into the wider community will be considered for key sites where data on cooperative behaviours and selection rates for domestication traits are available.

In this practical perspective, PPN households and their community-wide interactions can be considered as crucial factors for the creation of early arable habitats and the agro-ecological conditions under which domesticated cereals evolved. They represent the smallest socio-economic units that mobilised agricultural labour and shouldered the primary risks of food storage. Contextualising quantitative data for phenotypic domestication traits with these changing socio-economic environments will help better understand the 
nature of selection during the slow and protracted domestication process, and factors that established the conditions for selection. At the same time, this will help to better frame domestication as a co-evolutionary process, involving non-human and human partners which evolve together in multi-species collectives but not independently from each other [56].

This article aims to develop a socio-economic model for contextualising selection of domestication traits visible in the archaeobotanical record. I argue that the gradual development and changing interaction of PPN households represent key factors for understanding changing selection rates. I will concentrate on cereals, because this plant group provides the most extensive data basis, while direct and quantifiable evidence for cereal domestication exists in the form of non-shattering spikelets $[6,10,11]$.

\section{Socio-Economic Change and Cereal Domestication in Southwest Asia}

\subsection{PPNA $(11,700-10,700$ cal. BP)}

\subsubsection{PPNA Community Organisation and Food Storage}

In the broadest sense, PPNA settlements in and around the Jordan Rift Valley, along the middle Euphrates and in southeast Anatolia represent sedentary hamlets and villages that reached sizes of up to 5 hectares $[15,28,57]$. Residential structures are commonly undivided and circular or oval in outline, often semi-subterranean and sometimes built on stone foundations (Figure 2a). There are developments towards rectangular and multi-roomed structures at some sites towards the later part of the PPNA, for example at Jerf el Ahmar (Stordeur 2015), but also here circular huts preceded these architectural developments. The significant investment in the construction and maintenance of PPNA structures is traditionally taken as an argument for sedentism, but this cannot be equalised with a yearround occupation in general $[9,26,28,36]$. Residential buildings are commonly identified by associated 'domestic' artifacts and structures such as ground stone tools and hearths, although processing and cooking installations were often located in open spaces [15,30,58,59]. These patterns suggest that daily food processing, preparation and consumption involved a strong communal element $[26,30]$.

Despite limitations in detecting food storage in archaeological contexts $[49,60]$, the available evidence for PPNA food storage supports the general view that subsistence practices, including the storage and distribution of foods, were communally organised (Table 2). At Jerf el Ahmar, situated on the banks of the Euphrates in northern Syria, several subterranean circular structures have been excavated, each containing peripheral benches and two being partitioned into several cells (Figure 2a). The excavators interpreted these structures as communal buildings but also emphasise that they are too small to accommodate all inhabitants, so they possibly housed meetings of selected community members [61]. Within two of the cells in communal building 30, high densities of charred wild barley grains and chaff have been found, which Willcox and Stordeur [62] take as the basis for interpreting the cells as communal grain storage facilities. Additionally, in the earlier building 47, a concentration of charred wild rye or einkorn grains could represent grain storage as well, possibly once stored in a basket. This building also contained three aurochs' skulls and a hearth encircled by several pounders, which could link this possible grain storage to food processing in a ritual context $[26,62,63]$. The general suggestion of cereal storage in the communal buildings at Jerf el Ahmar is supported by the fact that no other buildings at the site seem to contain storage structures. Moreover, food processing implements such as large querns and stone basins were concentrated in some rooms of the rectangular houses, pointing to communal processing and food preparation activities as well $[62,64]$. A communal building with bins possibly used for storage, similar to building 30 at Jerf el Ahmar, is also known from Mureybet and comparable structures have been excavated at Tell 'Abr $[65,66]$. The sediments of the "public" building M1 at Tell 'Abr contained high densities of wild rye or einkorn grains, comparable to the finding in building 47 at Jerf el Ahmar. This large subterranean building also yielded aurochs bucrania, limestone basins and several querns [66]. Willcox et al. [67] likewise interpret this finding as indicative of a burned storage structure, which contributes to the general pattern 
of cereal storage in communal or public contexts at the middle Euphrates during the latter part of the PPNA. Altogether, the non-residential structures at several PPNA sites in the middle Euphrates region, together with the 'kitchens' at Jerf el Ahmar, seem to represent a consistent pattern where food storage and processing activities are related to communal and public structures.

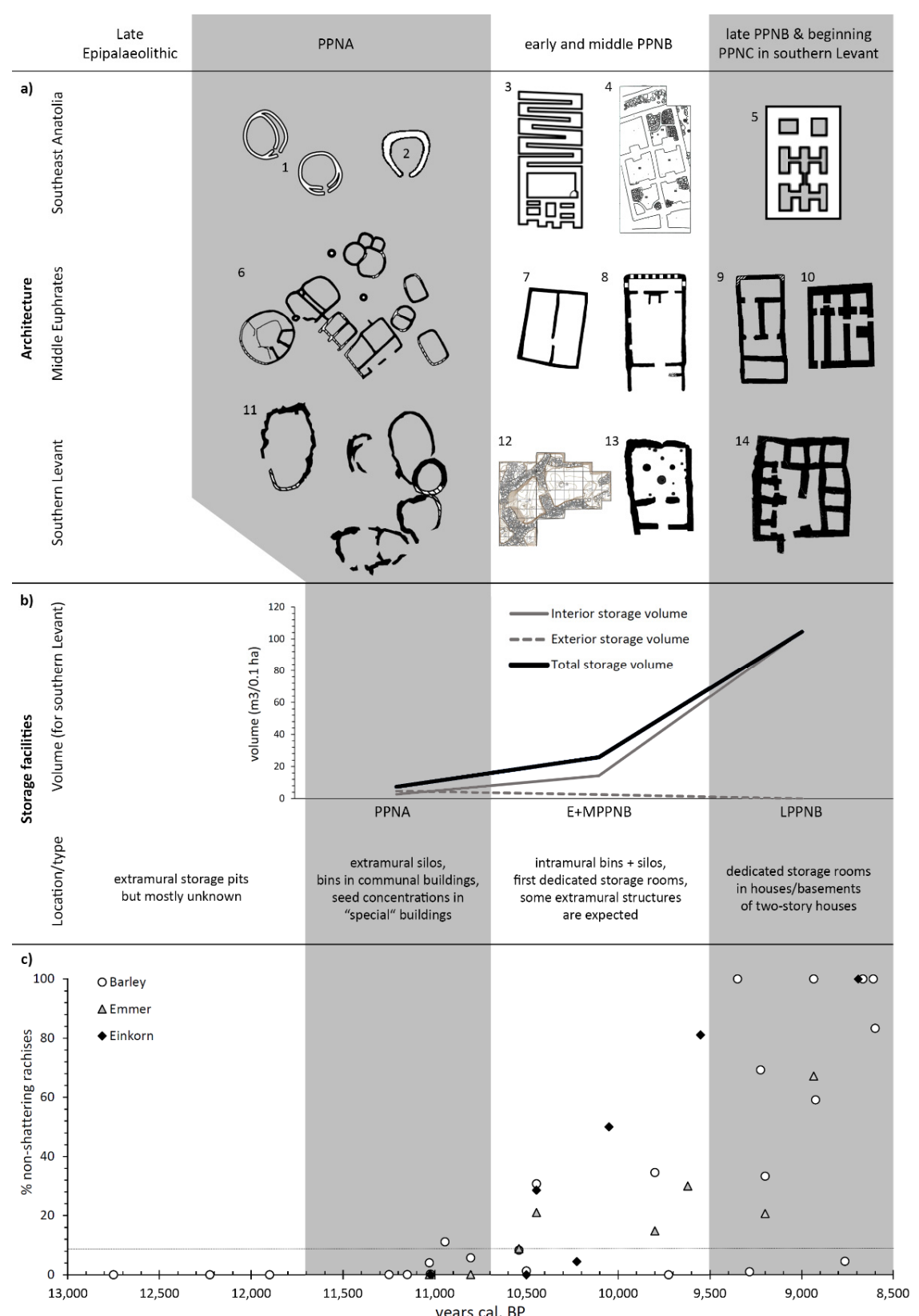

Figure 2. Correlation of architectural developments, storage systems, and proportions of nonshattering spikelets throughout the PPN. (a) examples for architectural developments (not to scale); (b) storage capacities and modes based on [33,55]; (c) proportions of non-shattering spikelets in charred cereal chaff assemblages, data based on [24] and modified (see Table S1 and Appendix A). Architectural plans redrawn from [32,36,68-70]: (1) Hallan Çemi (level 1), (2) Çayönü (round building subphase), (3) Çayönü (grill plan subphase), (4) Cafer Höyük (Level VIII), (5) Çayönü (cell building subphase), (6) Jerf el Ahmar (I/east), (7) Dja'de (phase 2), (8) Tell Halula, (9) Tell Abu Hureyra (phase 2B), (10) Tell Bouqras (phase III), (11) Netiv Hagdud ("upper area"), (12) Tell Qarassa North (area XYZ), (13) 'Ain Ghazal (house 4, MPPNB), (14) Basta (part of a larger courtyard building, area B). 
Table 2. List of possible PPN storage structures and contexts at selected sites.

\begin{tabular}{|c|c|c|c|c|}
\hline Site & Period & Storage Mode/Location & Evidence & References \\
\hline \multicolumn{5}{|c|}{ Middle Euphrates/Anatolia } \\
\hline Çayönü & PPNA & extramural & storage pits, sometimes plastered & [58] \\
\hline Jerf el Ahmar & PPNA & $\begin{array}{c}\text { intramural, } \\
\text { communal/ritual context }\end{array}$ & $\begin{array}{l}\text { high density of cereal grains / chaff in } \\
\text { cells of communal building and cereal } \\
\text { grain concentration in building with } \\
\text { aurochs bucrania }\end{array}$ & [62] \\
\hline Tell ‘Abr III & PPNA & $\begin{array}{c}\text { intramural, } \\
\text { communal/ritual context }\end{array}$ & $\begin{array}{l}\text { high density of cereal grains in } \\
\text { communal building with } \\
\text { aurochs bucrania }\end{array}$ & [62] \\
\hline Çayönü & early-late PPNB & intramural & $\begin{array}{l}\text { charred seed concentrations; no } \\
\text { extramural storage pits; storage rooms }\end{array}$ & {$[58,71]$} \\
\hline Cafer Höyük & middle PPNB & intramural & storage silos/bins & [68] \\
\hline Tell Halula & middle-late PPNB & intramural & storage rooms & {$[35,72]$} \\
\hline Çatalhöyük & $\begin{array}{c}\text { late PPNB/Pottery } \\
\text { Neolithic }\end{array}$ & intramural & bins in storage rooms & {$[34]$} \\
\hline \multicolumn{5}{|l|}{ Southern Levant } \\
\hline Jericho & PPNA & intramural + extramural & bins + possible silos around tower & {$[15,73]$} \\
\hline Netiv Hagdud & PPNA & intramural? + extramural & $\begin{array}{c}\text { bins (relation to residential structures } \\
\text { somewhat unclear), possible extramural } \\
\text { storage silo }\end{array}$ & {$[74,75]$} \\
\hline Gilgal I & PPNA & intramural & $\begin{array}{l}\text { cereal grains, Pistacia nutlets, acorns, } \\
\text { pulses and figs in baskets in paved } \\
\text { 'special building' }\end{array}$ & {$[76,77]$} \\
\hline Dhra' & PPNA & extramural & storage silos & {$[8,75]$} \\
\hline Wadi Faynan 16 & PPNA & extramural & storage silos & [75] \\
\hline $\begin{array}{l}\text { Tell Qarassa } \\
\text { North }\end{array}$ & early PPNB & intramural & possible storage pit in house & {$[70]$} \\
\hline Beidha & early-middle PPNB & intramural & charred Pistacia nutlets in baskets & {$[27,78]$} \\
\hline Jericho & middle PPNB & intramural & stone bins & [73] \\
\hline 'Ain Ghazal & middle PPNB & intramural & charred cereal/pulse deposit near door & {$[29,79]$} \\
\hline Yiftahel & middle PPNB & intramural & $\begin{array}{l}\text { charred pulses in clay silo and } \\
\text { perishable container }\end{array}$ & [80] \\
\hline Tell Aswad & late PPNB & intramural & $\begin{array}{l}\text { two large storage basins with high } \\
\text { densities of cereal remains }\end{array}$ & {$[81,82]$} \\
\hline 'Ain Ghazal & late PPNB & intramural & $\begin{array}{l}\text { storage rooms, one with accumulation } \\
\text { of charred pulse seeds }\end{array}$ & [29] \\
\hline Es-Sifyia & late PPNB & intramural & storage rooms & {$[49,83]$} \\
\hline Basta & late PPNB & intramural & storage rooms & {$[49,84]$} \\
\hline Ba'ja & late PPNB & intramural & storage rooms & {$[49,85]$} \\
\hline
\end{tabular}

Comparable non-residential buildings were long absent from excavated PPNA settlements in the southern Levant. The only larger structures that clearly represent communal building activities are the tower and the associated wall at Jericho [73]. Bar-Yosef [86] and Kuijt [87] interpret the tower as possibly linked to special rituals and referred to a collective burial situated in the tower entrance. Smaller structures around the tower have been considered to be communal storage facilities, although this is not fully clear [15,86]. Additional evidence for large communal structures was excavated at Wadi Faynan (WF) 16 
in southern Jordan [88]. Adjacent to smaller circular buildings, the excavators unearthed a $22 \times 19 \mathrm{~m}$ wide oval structure that comprises a multi-layered mud plaster floor and a decorated two-level bench over at least half of its circumference. Although the exact activities carried out in the structure remain unclear, Mithen et al. [88] refer to the tower of Jericho and the monumental enclosures at Göbekli Tepe [89] for highlighting its communal character in its construction and use.

Alongside such large structures, several free-standing storage silos have been excavated at WF 16, Dhra' and presumably also at Netiv Hagdud (Figure 2a). Finlayson et al. [90] interpreted structure 045 at WF 16 as a storage silo, because it provides evidence for a suspended floor and contains a smaller structure made of pisé walls. While it is clear that structure 045 is no good candidate for a simple residential dwelling, Finlayson et al. compare this silo from WF 16 to a similar structure at Dhra', which has equally been interpreted as a free-standing storage silo. Four such structures were excavated at Dhra' and the general reconstruction depends on one well-preserved example [75]. The authors draw particular attention to the in situ excavated upright notched stones, which presumably carried a suspended floor analogous to the structure at WF 16. Bar-Yosef and Gopher [74] reported comparable structures from Netiv Hagdud, although here the notched stones are missing. The excavators originally interpreted this structure as a possible storage silo, which the better-preserved structures from Dhra' and WF 16 seem to support. Due to their size and extramural character, these storage silos are thought to have been communally owned $[75,90]$. In addition, a large hoard of stored barley and oat grains was retrieved from a public building at Gilgal I, adding to the communal character of grain storage in the region $[76,77]$. By associating the large communal structure at WF 16 and the tower of Jericho with the widespread evidence for communal granaries, patterns emerge that are comparable to the possible storage facilities in communal buildings at several upper Euphrates sites $[75,90]$. The PPNA in the southern Levant and the Middle Euphrates therefore seems to be characterised by communal engagements in the construction of public buildings. The evidence for storage facilities in extramural and communal contexts makes it plausible to assume a communal organisation of cereal exploitation and possible management practices as well, including grain storage, processing, and distribution $[9,26,62]$.

These patterns are in accordance with anthropological models that relate communal storage with community-wide sharing networks and the active prevention of wealth inequalities [31,44,91-93]. Interestingly, researchers have emphasised that under such a strong community-oriented social organisation and the absence of individual ownership over food resources, incentives to invest in plant cultivation as a relatively labourintensive strategy would be suppressed [51-54]. However, PPNA plant exploitation strategies are usually characterised as the cultivation of morphologically wild cereals and pulses [6-8,20,62,67,75,76,94-96]. At least on a theoretical level, this stands in contrast to anthropological models that relate emerging cultivation to socio-economic variables, such as individual ownership over food resources and restricted food sharing networks.

\subsubsection{PPNA Plant Exploitation and the Socio-Economic Context of Low Selection Rates}

PPNA plant exploitation practices are commonly termed 'pre-domestication cultivation' (PDC). This model was mainly developed during the 1990s and the 2000s and assumes that PPNA communities started to cultivate wild plants, predominantly cereals and pulses, several millennia before domestication traits became visible in the archaeological record. The assumption that some grasses and pulses were cultivated by PPNA groups is based on various lines of evidence, including high amounts of recovered cereal and pulse remains $[67,76,97,98]$, the scale of storage and processing facilities [62,75], and the occurrence of species outside of their hypothesised early Holocene distribution range [67]. While these lines of evidence are indirect and do not necessarily rule out gathering from unmanaged stands, the identification of potentially arable weed floras is considered the most direct and reliable evidence for early cultivation activities [1,6-8,67,95,99-101]. Arable weed floras represent species communities that are adapted to the agro-ecological conditions 
in agricultural fields, which are determined by local environmental conditions but also husbandry practices $[102,103]$. These include activities such as tillage and weeding, which represent disturbances, and strategies to enhance productivity such as manuring and irrigation [104]. The main reasoning behind interpreting potential arable weed floras from PPNA botanical assemblages as indicative of cultivation practices is that they are thought to reflect increased levels of disturbance $[95,99]$. Therefore, arable taxa are taken as indicators for soil tillage and other disturbances such as vegetation clearance and weeding, which also serve as defining aspects of cultivation as a management practice [105]. In addition, many authors interpreted increased cereal grain sizes as indicative of cultivation $[4,5,7,8,100]$. The mechanisms that are selected for larger grains are not fully clear but functional ecological studies suggest that the large seedlings produced by larger grains gain more benefits in productive habitats and have a higher fitness than smaller seedlings [106]. Additional factors possibly include increased precipitation and $\mathrm{CO}_{2}$ levels during the Early Holocene, which would have increased grassland productivity $[9,107]$.

These uncertainties complicate a reliable reconstruction of PPNA plant exploitation strategies and associated management practices. Whether PDC reflects the continuous cultivation of grains in arable fields, or other forms of resource management strategies that do not involve annual cycles of tillage and sowing is currently not fully clear. Weide et al. [108] argued that the selection of potentially arable weeds used to reconstruct early cultivation is flawed as the taxa, mostly genus identifications, include species that occur in local grasslands and cannot be used to distinguish arable from non-arable habitats $[109,110]$. Plant remains of genera that include crop mimics such as Bromus, Lolium, and Phalaris only increase in frequency after the PPNA, suggesting that arable environments which were selected for domestication traits were not widespread during the PPNA [3]. We might expect significant variability in plant exploitation practices between sites and regions in southwest Asia [9], where annual cultivation systems represent the extreme end of a diverse spectrum of possible management practices [111]. From this perspective, and in light of the architectural, social, and demographic developments towards generally larger and more sedentary villages in the PPNA, it is still somewhat surprising that the archaeobotanical record did not produce any reliable evidence for increased proportions of non-shattering cereal ears (Figure 2c; Table S1; Appendix A).

Under the assumption of widespread cultivation practices, this has traditionally been explained with a hypothetical mix of husbandry practices that would select against nonshattering ears in cereals. These include harvesting green ears to prevent grain loss through shattering, collection of shed spikelets from the ground, the continuous cultivation of wild cereals in the same fields, where shattered spikelets contribute significantly to the population in the following year, and collecting grains from non-arable habitats for replenishing seed stocks after failed harvests $[6,10,14,19,67]$. The key principle behind these possible 'non-selection' scenarios is that some cultivation and harvesting practices continuously mix populations that are under selection for non-shattering ears with populations where exploitation practices favour shattering spikelets, or at least do not discriminate against those such as ground collecting. As a result, cultivated lineages that are under selection for specific traits are not genetically isolated and geneflow between populations that reproduce under different (agro-)ecological conditions is maintained at a level that prevents the genetic fixation of domestication traits [23,112]. This means that a key requirement for selection is that the variability of ecological conditions within a subpopulation is reduced and that this subpopulation becomes genetically isolated from other subpopulations where selection favours other phenotypes. It is, however, unclear whether and to which extent these 'non-selection' practices are reflected in PPNA archaeobotanical data. In fact, except for harvesting high proportions of semi-ripe ears with sickles [20,96], all of these explanations are speculative and not based on direct archaeological evidence. While we cannot solve this issue here, we can situate the hypothetical PPNA cereal exploitation system in its specific socio-economic context and model how the archaeologically documented practices would affect selection for domestication traits. 
The basic stages of the exploitation of annual plants for their seeds encompass harvesting, processing (threshing, dehusking, sieving), storage, food preparation, and consumption. When we assume some form of resource management, additional stages may encompass vegetation clearance, tillage, sowing, weeding, and other potential activities $[105,111]$. As discussed, in household-centred farming communities, these stages can either be performed by individual households, or by several households that cooperate and pool labour and resources [50]. For PPNA communities, the archaeological record implies a high degree of community-wide cooperation in all stages of the plant exploitation and processing activities as discussed above. Figure $3 a$ illustrates this in the form of an idealised model, where I refer to the fully communal organisation of cereal exploitation, storage, and food distribution as "type 1" strategy. This model assumes that large amounts of grains were stored in communal storage facilities, from where they were redistributed among members of the community. While sites like Jerf el Ahmar in the northern Levant had only one communal building with storage bins at a time [61], sites in the southern Levant, such as Dhra' and WF 16, likely had several contemporaneous storage silos that were used by a fraction of the community, possibly large extended households or corporate groups [75]. This type 1 strategy could therefore apply to an entire community, or to corporate groups within a larger community. However, this is of minor importance for the effect of communal storage on selection rates. Whether the harvested grains were stored in one central granary or in several communal silos, grains harvested from different cereal populations would inevitably be mixed and populations that were under stronger selection regimes for traits such as non-shattering ears (e.g., harvested in a ripe state with sickles from sown populations) would not be genetically isolated from populations that were not under selection for non-shattering (e.g., harvesting semi-ripe ears and regular ground collecting). Even when we assume that grains from individual harvests were not fully mixed in storage bins and silos but stored in individual containers, for example baskets, the communal character of PPNA storage facilities implies that the use and redistribution of the stored grains was not in control of the social units that contributed the individual harvests to the communal grain stock. Mixing of grains from different populations would then likely occur when grains are re-sown to maintain the exploited stands. Importantly, wild cereal stands can efficiently reproduce from shattered spikelets in the year after being harvested [113]. If sowing only occurred every few years to maintain stands, selection for non-shattering would be significantly reduced. An additional and perhaps key factor would have been the regular replenishing of seed stocks from unmanaged populations to cope with poor harvests, a likely "fall-back" strategy that might have been part of early cereal management practices for centuries $[10,23,67]$.

This socio-economic model argues that the community-wide cooperation in food exploitation, storage and distribution, and the vicinity of most PPNA settlements to local unmanaged populations, explains the very low-or absent-rates of selection for non-shattering during this period. The absence of domestication traits from the archaeobotanical record during the PPNA is therefore expected rather than paradoxical. Cereal exploitation regimes may have involved active management but did clearly not create the agro-ecological conditions that were later selected for domestic phenotypes. This is expected in the communal socio-economic system, and the following discussion argues that the higher labour inputs associated with an intensified annual cultivation regime that accelerated selection could only be realised by the smaller household units that emerged during the PPNB. 
(a)
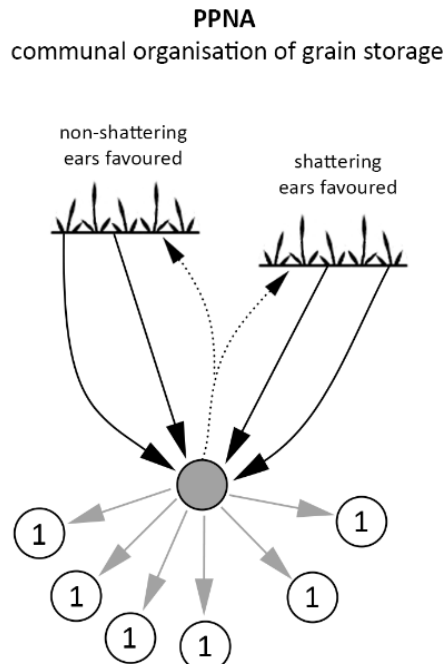

(1) (1)
(1)

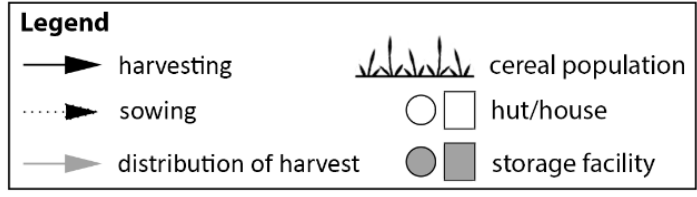

mixing of populations under different selection pressures for domestic traits in communal granaries

no or very weak selection for domestic traits

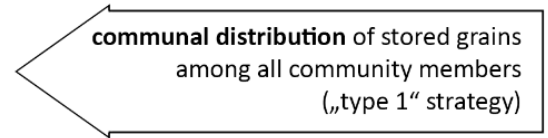

(b) in small households (about the size of a nuclear family)
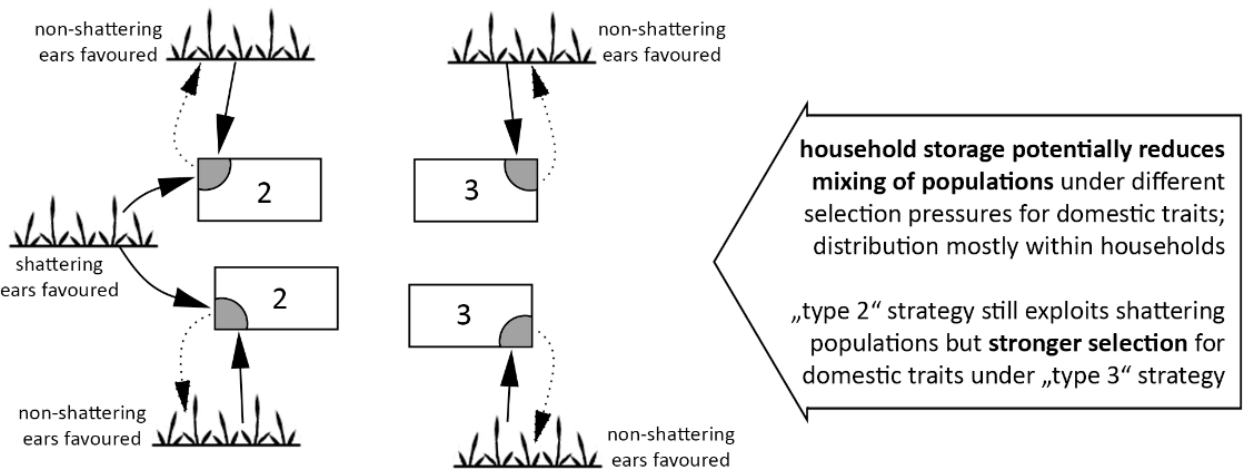

populations but stronger selection for domestic traits under "type 3 “ strategy

(c)

late PPNB

increasing storage capacities in extended households, where individual co-residential units may collaborate

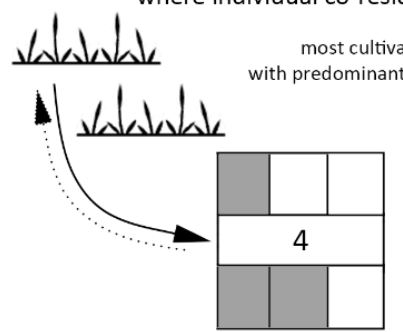

ated population

statak
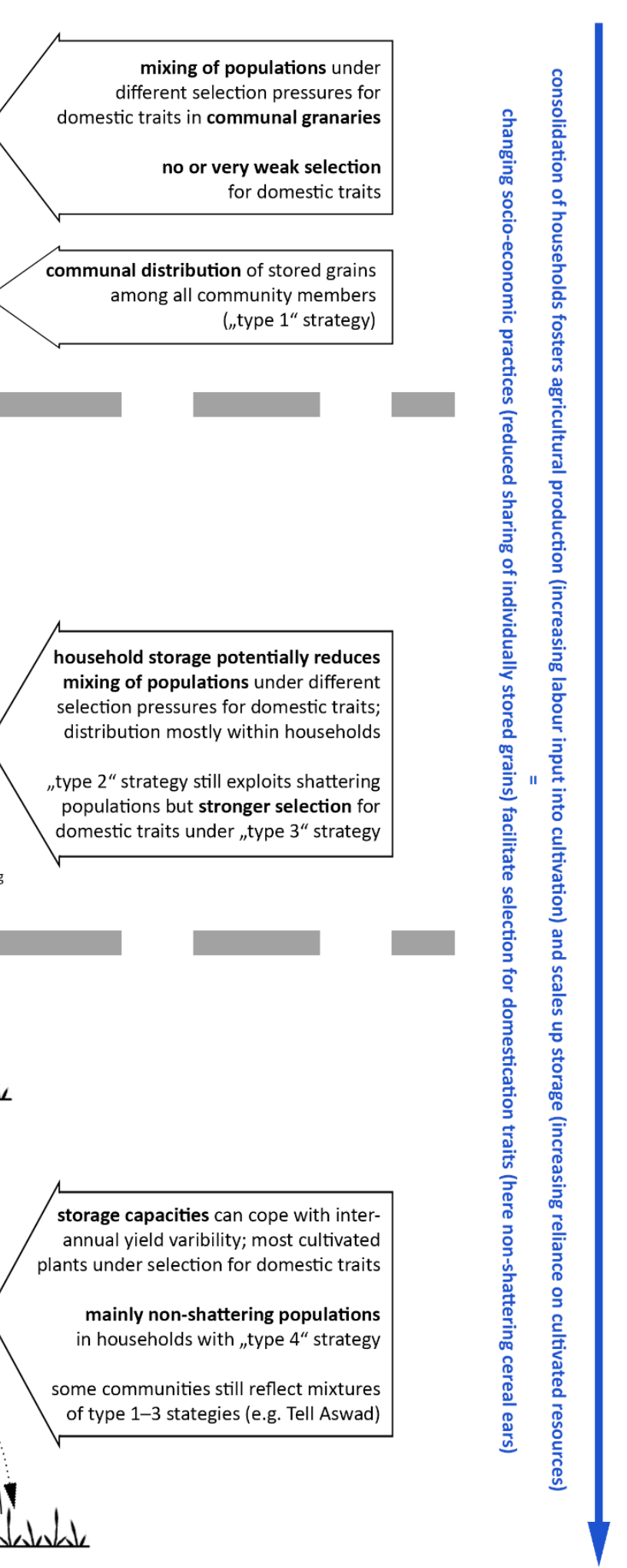

Figure 3. Idealised model for the development of household-centred storage and cultivation systems throughout the (a) PPNA, (b) early/middle PPNB, and (c) late PPNB, and their hypothetical effects on selection for non-shattering cereal ears. 


\subsection{Early to Middle PPNB (10,700-9500 cal. BP)}

\subsubsection{Changing Household Organisation and Restricted Food Sharing Networks}

Architectural and associated social developments in the southern Levant, the middle Euphrates, and southeast Anatolia during the early and middle PPNB are characterised by the widespread appearance of rectangular, multi-roomed buildings and the disappearance of extramural and communal storage facilities (Figure 2a). The appearance of larger, rectangular buildings is often referred to as a formalisation of space and a consolidation of co-resident groups, perhaps nuclear family households or at least groups of this size, that coincided with the construction of predominantly internal storage facilities $[27,29-33,55]$ (Table 2).

For the southern Levant, Kuijt [55] provided data on the scale of extra- and intramural storage from selected sites (Figure $2 b$ ). Although evidence for intramural food storage exists throughout the entire PPN, he showed that the volume of extramural storage structures was highest during the PPNA, whereas the ratio was inverted by the middle PPNB, where intramural storage became the principal storage mode. This is best documented by Yiftahel, where large concentrations of horsebean seeds and lentils were found inside the central room of a tripartite structure, the former inside a clay storage bin that was constructed in the corner of the room [80]. Comparable seed and fruit accumulations were identified in two buildings at Beidha (pistachios stored in baskets) $[27,78]$ and in a separate storage area near the house's entrance at 'Ain Ghazal (concentrations of cereals and pulses) $[29,79]$. This shift of plant storage facilities into houses is mirrored by a general relocation of food processing and preparation activities towards locations near house entrances and porches, which reflects a stronger association of these activities with individual co-resident groups in the early and middle PPNB as opposed to the PPNA [30]. Food processing and preparation still maintained a strong public element, as these activities were not hidden from other households. In contrast, Wright suggests that food consumption often took place in houses, indicated by hearths in the largest room of the standardized PPNB pier houses. If correct, this would indicate an interesting 'hierarchy' in household-centred subsistence activities in the middle PPNB, where crop processing and food preparation retained a public element, whereas food storage and consumption were increasingly 'privatised'. The public character of crop processing and food preparation possibly reflects earlier traditions of a fully communal organisation of subsistence practices and helped to integrate these smaller households into the community, while they gained more control over the use of individual harvests $[30,34]$. Plant processing, however, represents a particularly labourintensive stage in agricultural systems, which is often associated with supra-household cooperation and labour-pooling [50]. The persistence of public or communal elements of subsistence activities in early and middle PPNB communities is therefore fully expectable and may not only reflect social pressures but also economic necessities.

Comparable evidence for changes in storage practices comes from sites at the Middle Euphrates. The storage bins in communal buildings at Jerf el Ahmar and Mureybet disappear towards late PPNA. Storage facilities could not be identified in early PPNB Dja'de [114], however, the middle PPNB site of Tell Halula provided clear architectural evidence for household storage. Houses at Halula were highly standardised and composed of a front porch, a central room with an oven, and two small storage rooms in the back (Figure 2a) [72]. Small storage bins, or silos, were located inside these storage rooms and in front of houses, confirming that storage was associated with individual residential units. Oriented on the size and layout of buildings and number of burials, each of these buildings should represent a co-residential household of the size of a nuclear family that together engaged in agricultural tasks, food storage, and consumption [35].

Evidence for changing storage practices in southeast Anatolia reflect comparable patterns, confirming that the shift from PPNA extramural and communal storage to early-middle PPNB household storage was a pan-regional phenomenon. Extramural storage pits were located between residential structures in the earliest "Round Building Subphase" at Çayönü, dating to the PPNA (Figure 2a) [58]. Similar pits in open areas were dug and plastered during the 
late PPNA "Grill Building Subphase" (Figure 2a), before most daily activities were moved in front and inside of houses towards the early PPNB. This was likely accompanied by a shift in storage practices, as no extramural storage pits were documented at PPNB levels. The fact that the inhabitants of Çayönü carefully cleaned houses before they destroyed and "buried" them for the construction of new buildings explains why indoor storage facilities like small bins or remains of stored plant remains are very rare. An exception represents the accumulation of charred Lycium-type seeds in an early PPNB channelled building, indicative of intramural seed storage [71]. Additional evidence for middle PPNB intramural storage in southeast Anatolia comes from two multi-roomed buildings at Cafer Höyük [68] (Figure 2a). Several rooms in these houses contained storage bins with paved floors. These buildings date to the middle occupation phase of the site (levels VIII-V; early 10th millennium cal. BP) and were preceded by smaller houses without evidence for intramural storage facilities in the site's early phase (levels XIII-IX; late 11th millennium cal. BP). Moreover, the structures from Tell Halula and Cafer Höyük provide the earliest known examples of dedicated storage rooms in southwest Asia.

This pan-regional shift from extramural and communal to intramural storage implies a more restricted access to the stored materials, which would have been controlled by the co-residential groups that inhabited the individual buildings $[33,55]$. Traditional anthropological models commonly relate a visually and practically restricted access to stored goods to some form of private ownership [52,53,91,115], and many archaeologists have interpreted this trend as the gradual 'privatisation' of food storage, linked to a shift in ownership principles and food sharing practices $[31,33,34,44,55]$. This development is associated with the expectation that increasingly independent households have higher incentives, but also abilities, to mobilise agricultural labour and to increase their reliance on cultivated foods. Interestingly, the early and middle PPNB also coincides with the appearance of the first increased proportions of non-shattering cereal spikelets, indicative of increased selection rates and early genetic fixation of domestication traits [12,24]. A major question for understanding cereal domestication is, therefore, how the changing community organisation and the emergence of small, co-residential households were related to higher selection rates.

\subsubsection{Increasing Selection Rates as a Function of Household Size and Limited Food Sharing}

Archaeobotanical assemblages with reliable evidence for increased proportions of non-shattering cereal ears show a remarkable correlation with sites where a shift towards household-centred storage and crop processing is documented archaeologically. The early PPNB site of Tell Qarassa North in southern Syria, occupied between ca. 10,700-10,200 cal. $\mathrm{BP}$, provided chaff of emmer wheat, einkorn, and barley that comprised between $21-30 \%$ non-shattering spikelets $[12,70]$. These proportions clearly exceed the threshold of $10 \%$ nonshattering spikelets that occur among modern wild barley and emmer populations [116,117] indicating that selection towards non-shattering ears resulted in the establishment of nonshattering phenotypes in the harvested populations. Ibáñez et al. [96] showed that people at Tell Qarassa harvested much higher proportions of dry and ripe cereal stems compared to earlier sites in the region. This should be a result of selection for non-shattering, as plants can be harvested at a later stage, and could further accelerate selection because higher proportions of shattering spikelets should be lost before harvesting. Due to the short occupation of the site, we unfortunately cannot track this local selection chain through time. Cereal chaff at Tell Qarassa was concentrated in several samples from the outside area (space B, or 'patio') of the excavated semi-rectangular structure (Figure 2a), where it was associated with a grinding slab, mortars and pestles. Due to a scarcity of chaff from the indoor area of the same residential structure (space A), Arranz-Otaegui et al. [70] conclude that cereal processing took place in front of this house. An adjacent structure (space $\mathrm{C}$ ) was only partially excavated but contained a second grinding slab, suggesting that the two excavated structures could represent co-residential units that organised their own food processing activities. A possible storage pit inside the interior space (space A) of 
the fully excavated structure, associated with collapsed adobe fragments and botanical samples dominated by cereal grains, is in line with the general shift towards intramural storage in the early PPNB [70]. These patterns match the general shift towards householdcentred storage and processing in the early PPNB, here clearly associated with the earliest evidence for selection towards non-shattering cereals. The fact that crop processing and dehusking took place in front of a residential unit may suggest that no collective postharvest processing took place [50] and that this household may have controlled most stages of the cereal cultivation and processing process. We must note, however, that the limited exposure at Tell Qarassa limits our understanding of the use of space and potential supra-household cooperation.

Tanno and Willcox [11] revisited the cereal chaff assemblage from early PPNB Nevalı Cori, which Pasternak [118] identified as domesticated. Based on a revision of identification criteria, they concluded, however, that the einkorn-dominated hulled wheat remains conform to predominantly shattering populations with only about $4 \%$ of non-shattering spikelets. Based on this surprising result, they also emphasised the need to re-examine the cereal chaff from Çayönü, which van Zeist and de Roller [71] identified as domesticated without giving clear identification criteria. It seems clear that barley chaff from Çayönü is of the shattering type [71,119], which demands caution in relating the well-studied architectural developments to a local cereal domestication process.

Reliable evidence for increased proportions of non-shattering cereal ears in southeast and central Anatolia derives from the sites of Cafer Höyük and Aşiklı Höyük, dating to the beginning middle PPNB after ca. 10,300 cal. BP [11,120,121]. The cereal assemblage from Cafer Höyük provides reliable evidence for high and continuously increasing proportions of non-shattering einkorn spikelets from the earliest level XIII onwards [120]. To what degree the two- and three-roomed structures from the early levels reflect household units is not fully clear. The earliest two-roomed structure from level XII [68] is reminiscent of comparable structures at Jerf el Ahmar and Dja'de, where individual buildings cannot be equalised with households as socio-economic units [61]. Whether this also applies to Cafer Höyük is unclear but the slightly younger tripartite building in level $\mathrm{X}$ shows an architectural compartmentalisation, reflecting a growing emphasis on house-centred activities we see throughout southwest Asia in the middle PPNB. This architectural development continues into the middle phase at Cafer Höyük (levels VIII-V), where two multi-roomed and possibly two-storey houses each had several dedicated storage rooms on the ground floor [68] (Figure 2a). This architectural development signals the organisation of food storage at the level of these co-residential units and is associated with a rise of non-shattering einkorn spikelets from $30 \%$ to 80 , comparable to the situation at Tell Qarassa.

The significance of household-centred storage and crop handling activities for increasing selection rates becomes clearer when we turn to sites where selection rates remained low during the early and middle PPNB. Remarkably stable proportions of shattering hulled wheat and barley rachises were documented by Ergun et al. [121] for the sequence at Aşikl Höyük in central Anatolia. Between levels 5-2, over a period of more than 600 years, the proportions of non-shattering spikelets did not increase but fluctuated between ca. 30-60\%. This indicates that selection rates at Aşiklı Höyük were not strong or stable enough to establish higher proportions of non-shattering spikelets but maintained what Fuller et al. [25] called a 'meta-stable equilibrium'. In a careful analysis of architectural developments and the use of space throughout the sequence, Duru et al. [42] recently showed how households reconfigured their economic organisation during the occupation period. During the lower levels 5-4 (ca. 8350-8050 cal BP), fireplaces and grinding stones were located inside and outside of the round buildings, a pattern that does not suggest a strong division of public and private space. In level 2, rectangular buildings became the norm, and most domestic activities were gradually relocated to the inside of buildings and to rooftops [122]. Within this occupation phase (7750 to $7350 \mathrm{cal} \mathrm{BP}$ ), a gradual compartmentalisation of indoor space transformed the earlier single-roomed rectangular buildings into two- or three-roomed buildings. These later rectangular buildings display an interesting functional division, 
where fireplaces and storage bins exclude each other. Only $40 \%$ of the buildings of the later phases of level 2 contained a hearth [123]. The storage bins, which now also indicate larger volumes of stored grains, are only found in the buildings without a hearth, implying food storage and preparation facilities were shared between co-residential units. This means that the inhabitants of individual buildings at Aşiklı Höyük were not economically independent but formed extended households that shared economic facilities and pooled resources with neighbours [42,124]. As other stages in the agricultural cycle, including the allocation of arable plots, are often subject to cooperation among much more autonomous households [50], we may assume that these extended households also cooperated in crop cultivation and subsequent labour-intensive tasks such as post-harvest processing. At Aşiklı Höyük, these signs of a collaborative, supra-household organisation of agricultural tasks are associated with selection rates for non-shattering cereal ears that were close to zero.

Dja'de at the Middle Euphrates represents another early PPNB community that exploited cereals but did not induce strong selection for non-shattering ears. Cereal chaff remains from the site contain very small proportions of non-shattering spikelets that are not indicative of a local selection process [82]. Although communal storage facilities had already disappeared from the archaeological record of the region in the latest phase at Jerf el Ahmar, the relatively small rectangular houses at Dja'de did not provide clear evidence for intramural food storage [114]. Evidence for food preparation and consumption are derived predominantly from extramural features, including fire pits associated with charred cereal remains. The grill-plan structures that appear in the middle occupation phase may have been associated with extramural storage, although this is not fully clear [114]. Taken together, these patterns suggest that Dja'de stands in a local tradition of communally organised plant exploitation and consumption activities such as at PPNA Jerf el Ahmar [26,62], clearly linked to the persistence of shattering cereal populations.

How exactly would these socio-economic patterns relate to the selection or nonselection of domestication traits? A first assumption can be deduced from the development of co-residential units that have their own storage facilities and individually process crop harvests. This development is evidenced in the pan-regional architectural and artefactual record of the southern Levant (e.g., Tell Qarassa, Beidha, Ain' Ghazal), middle Euphrates (Tell Halula), and southeast Anatolia (e.g., Cafer Höyük, Çayönü), although the direct link between household storage and early selection for non-shattering can only be demonstrated for two of these sites. A key factor that changed with this socio-economic development is the size of the group that together engaged in cultivation activities, storage, processing, and consumption. For Dja'de and Aşiklı Höyük we can assume, due to the absence of clearly demarcated co-residential units that each stores their 'own' foods, that agricultural tasks were jointly performed by relatively large extended household groups. In contrast, the evidence from Tell Qarassa and Cafer Höyük, but also Tell Halula, Beidha, etc., reflect the atomisation of the community into smaller socio-economic units, which increasingly organised food storage, processing, and consumption on the level of individual households that many researchers regarded as nuclear families. Independently from kinship relations within and between these households, they must have been relatively small and conformed to the size of nuclear families, given the size and layout of the standardised residential units they inhabited [40].

Figure $3 \mathrm{~b}$ illustrates this situation as an idealised model, where every 'nuclear familysized' household is represented by a building with an internal storage bin, oriented on the discussed early and middle PPNB record (Figure 2a). The archaeological record further demonstrates that these small household units did not only store grain inside their houses, but that food processing, preparation, and consumption activities were increasingly associated with individual buildings $[27,30,58,70]$. For Tell Qarassa, there is evidence that dehusking was also performed by these households in front of residential units, a sign that post-harvest and pre-storage processing was not collectively performed [50]. These patterns together imply that these early households gradually gained control over the cultivation 
and food distribution process, which is traditionally interpreted as reflecting the development of 'private' or household-centred property rights over cultivated foods [31,34], but see $[42,52,91]$. Independently from the potential ideas of ownership and private property, however, this practically means that food sharing between households became restricted.

Such a changed socio-economic environment would result in a subdivision of the cultivated cereal population into several subpopulations, each representing a lineage cultivated by a household unit. Depending on the household-specific husbandry regimes, these increasingly separated lineages may experience different selection rates for non-shattering ears, as simple factors such as harvesting techniques can easily reduce selection for nonshattering ears [14,112]. In addition, socio-economic factors including household size, composition, and the distance of cultivated plots from settlements, which determine how much labour per area of cultivated land a household can realise, influences household decision-making and the specific cultivation regime [125-127]. It is therefore expected that the separation of cultivated lineages by relatively small, individual household units principally coincided with a reduced variability of cultivation and harvesting techniques within the separated subpopulations but maintained variability between subpopulations and on a population-level. Some of the lineages should have experienced stronger selection for nonshattering ears than others, with those that were under selection for non-shattering being genetically isolated from populations where shattering spikelets were favoured. A source of continuous mixing of these subpopulations would have been supra-household cooperation in the most labour-demanding tasks such as post-harvest crop processing [50]. These variable factors also help to explain the large differences in proportions of non-shattering spikelets among assemblages from early-middle PPNB sites (Figure 2c; Table S1).

In this model, a hypothetical "type 2" strategy would not induce strong selection pressures for non-shattering in the cultivated subpopulation (Figure 3b). This could involve a 'non-selective' cultivation regime (e.g., harvesting semi-ripe ears before they shatter) and/or a partial reliance on non-arable cereal populations that reproduce through selfsowing via shattering spikelets. According to the archaeological record, 'non-selective' cultivation regimes prevailed at Dja'de and Aşiklı Höyük, with selection rates for nonshattering ears close to zero [11]. The supra-household or perhaps community-wide cooperation in agricultural activities, including regular labour-pooling and food sharing between co-residential units, means that the managed cereal subpopulations experienced a higher variability of selective pressures and lower genetic isolation, which represent key factors why selection remained so low at these sites. In contrast, the hypothetical "type 3 " strategy would impose stronger selection for non-shattering ears, mainly because mixing of grains with populations where shattering spikelets are favoured is significantly reduced (Figure 3b). This scenario applies to Cafer Höyük and Tell Qarassa, where nonshattering phenotypes increased within subpopulations that were individually managed by relatively small households. The size of the group that together engaged in crop cultivation, storage, and consumption therefore represents a key variable that determined selection rates during the PPNB - where small households are associated with higher selection rates and supra-household strategies with lower selection rates.

As Figure $2 \mathrm{c}$ shows, all early-middle PPNB cereal chaff assemblages contain considerable proportions of shattering spikelets, and fully non-shattering assemblages only appear at some sites during the late PPNB. The atomisation of communities into smaller household units with internal crop storage facilities therefore seems to have accelerated selection locally and only in specific situations but did not result in a rapid fixation of non-shattering on a meta-population level. To fully understand the cereal domestication process from a socio-economic perspective, we must therefore consider late PPNB developments and the conditions under which fully non-shattering populations emerged. 


\subsection{Late PPNB (9500-8700 cal. BP)}

\subsubsection{Consolidation of Household-Centred Agricultural Strategies}

Developments during the late PPNB in the southern Levant, the Middle Euphrates, and southeast to central Anatolia are commonly described as a consolidation of earlier socio-economic processes and the emergence of extended households, where smaller social units pool labour and resources $[15,27,29,30,32-34,36,46]$. Archaeologically, this is manifested in the construction of much larger buildings with a more complex internal compartmentalisation, reflective of the social and economic activities that were increasingly associated with these residential units.

In the southern Levant, this process is reflected at sites such as Basta, Beidha, Es-Sifyia, or 'Ain Ghazal, where two-storey buildings were built with multiple small rooms on the ground floor that were usually accessible through half-doors $[27,29,83,84]$. These buildings were considerably larger than the typical middle PPNB pier houses and sometimes rooms were arranged around a central courtyard, such as at Basta or Ba'ja $[84,85]$ (Figure 2a). Although the social composition of the social groups that lived in these compounds is not fully clear, most archaeologists interpret these architectural developments as signalling the appearance of extended households [29,31,32,45,46,48,128]. For the sequence at 'Ain Ghazal, for example, Rollefson [29] suggested that the development towards larger, twostorey houses reflects the amalgamation of several nuclear families into an extended household, which allowed to pool labour and agricultural resources. In this sense, the larger extent of late PPNB villages east and south of the Jordan valley, with larger houses and house complexes, was also the result of a social and economic reorganisation and not only based on population growth [33].

A key feature of these architectural developments are the small cells on the ground floor of most two-storey and courtyard buildings, which are generally interpreted as storage rooms $[30,33,49]$. Unfortunately, however, direct evidence for plant storage in these cells is very rare, also due to the fact that the archaeobotanical analyses of many late PPNB sites have not been fully published. Only at 'Ain Ghazal, high concentrations of charred lentils and peas were found in two of the cells of a late PPNB building and support their interpretation as food storage areas [29]. Although other materials were likely stored in these small rooms, the high numbers of grinding and milling tools, frequently associated with oven remains and hearths, clearly suggests a close association of food storage, processing, preparation, and consumption inside these buildings [30]. For 'Ain Ghazal, Bogaard [50] interprets this development as a shift in cooperative behaviours: middle PPNB nuclear households stored crops privately but in relatively accessible locations (e.g., near front door), while storage and processing were increasingly separated from public areas and moved into late PPNB houses, possibly signalling a further reduction in supra-household cooperation in labour-intensive stages like crop processing. This suggests that older trends towards a 'privatisation' of food storage and consumption culminated in the late PPNB, where small social units (e.g., nuclear families or other symbolically constructed groups) closely cooperated and lived together in extended households, which allowed them to mobilise enough labour to gain full control over the handling and distribution of their crop harvests. Cooperation beyond these extended households would still be expected, however, in issues such as allocating productive arable land among households [46,50].

As Kuijt [55] showed, this development coincided with a significant increase in storage capacities in the southern Levant. While storage space already grew from the PPNA to the middle PPNB, the late PPNB saw a further massive increase in storage capacities due to the construction of dedicated storage rooms (Figure $2 b$ ). Based on a wide range of ethnographic data on spoilage rates and the amount of grain farmers usually hold back for planting, he estimated that late PPNB communities in the southern Levant were the first to store enough grains to cope with inter-annual yield variability and loss through grain spoilage during storage. This rests on the assumption that traditional farming communities commonly aim to store enough food 24 months or more [125,129], and that soilage rates approach $100 \%$ when grains are stored for longer in traditional facilities such as storage 
pits [130-132]. Demonstrably, this marginal food excess did not lead to a strong social differentiation or wealth inequality $[55,93]$ but likely represented an insurance against low yields and spoilage of stored grains. As we will discuss in more detail below, this development significantly changed the abilities of early farmers to plan for several years and fully rely on their cultivated crops, even when bad years would regularly result in significant yield losses or complete crop failures [125].

Late PPNB socio-economic developments along the Middle Euphrates and in southeast Anatolia were comparable to those in the southern Levant. At Tell Halula, house architecture did not change significantly during this time period, where small storage rooms were already present at the back side of houses since the middle PPNB (Figure 2a) [35,72]. However, two-storey buildings of variable sizes and with small rooms on the ground floor were also built at Bouqras and Çayönü (Figure 2a) [58,133,134]. Akkermans et al. [133] argue that the small cells at Bouqras were used for food storage and preparation, as they were associated with oven remains. The large concentrations of cereal grains retrieved from three burnt houses confirm this suggestion, although the exact location of these stored grains was not given [135]. At Çayönü, house architecture during the "Cell Building Subphase" is reminiscent of the developments in the southern Levant, with ground floors of houses containing a series of cells that were sometimes arranged around a central room or courtyard [58]. An almost pure concentration of bitter vetch seeds was found in the fill of one cell-plan building, suggesting that these rooms were also used for food storage, although detailed information on the location of this concentration is not available [71]. This situation is better at Seker al-Aheimar, located in the Khabur valley in northern Syria, where Portillo et al. [136] identified high concentrations of cereal chaff phytoliths in the small rooms of a late PPNB courtyard building and in a bin in the courtyard itself, providing evidence that these cell-like rooms served as food storage areas. Despite variation in residential architecture and settlement organisation across the Levant and southeast Anatolia, the available evidence reflects highly convergent socio-economic developments towards a larger scale of household storage in dedicated storage rooms, related to the abilities of extended households to mobilise more resources for agricultural production and storage.

\subsubsection{Towards a Full Reliance on Cultivated Populations}

Proportions of non-shattering spikelets rarely exceeded $30 \%$ in early-middle PPNB assemblages, while they now contribute more than $60 \%$ to the cereal chaff of most sites (Figure 2c). The first fully non-shattering populations emerged during the first half of the late PPNB at the Middle Euphrates and in the Khabur valley in northern Syria, at the sites of Abu Hureyra (barley, phase 2B) [120] and Seker al-Aheimar (barley; emmer wheat with ca. $66 \%$ non-shattering, see Table S1 and Appendix A) [11]. We still see considerable variation in the proportions of non-shattering spikelets and changing phenotypic composition beyond the PPN, indicating that the cereal domestication process and selection for different phenotypes continued $[13,137]$. Here we concentrate on the first appearance of predominantly non-shattering populations and how this process related to socio-economic developments.

Key variables that changed towards the late PPNB were storage and the interaction of the small household units of the early-middle PPNB. The much higher storage capacities suggest that the extended households were now able to store enough grain for coping with inter-annual yield variability-despite the inevitable spoilage of significant amounts of the stored crops (Figure 2b) [55]. If correct, this should have resulted in enhanced food security for the extended households, which could only be achieved through further labour investments in the construction of storage space and the continuous cultivation of cereal populations. For the cultivated cereals this meant that the isolation from shattering populations that were not under continuous cultivation was further increased, as illustrated by the hypothetical "type 4" strategy (Figure 3c). Most importantly, due to the increase in storage capacities, extended households could now rely on their cultivated cereal population for 
more than one year without the need to re-stock their grains after poor harvests or to make up for spoilage losses. The necessity to fall back on locally available wild cereal resources would have been increasingly unlikely due to the investments in cereal cultivation and long-term food storage.

The development of new storage technologies and higher capacities by extended households represents one of the most crucial processes that links social factors to selection rates. From a social perspective, the agricultural systems that could cope with inter-annual yield variability were based on the amalgamation of small co-residential household units in extended, collaborative households. According to this model, the slow and gradual increase in non-shattering spikelets among archaeobotanical cereal chaff is a function of gradually changing social and economic practices and helps to explain why the cereal domestication process in southwest Asia was so slow: because the socio-economic environment that gradually established the conditions for selection was slow to develop.

We conclude this overview with a brief discussion of the recent results from Tell Aswad in the Damascus basin, which once more reinforce the argument that the consolidation of households as the basic units of agricultural production and consumption drove selection rates during cereal domestication. Based on a revision of Aswad's chronology and the completion of archaeobotanical analyses, reliable evidence for increased proportions of nonshattering barley and emmer spikelets now dates to the middle PPNB (phase 2) [82] and not anymore to the early PPNB as suggested earlier by Tanno and Willcox [11]. Percentages of non-shattering spikelets remained low, however, and only reached ca. 33\% for barley and ca. $20 \%$ for emmer wheat in the late PPNB (Table S1). A similarity to other sites with such low selection rates is seen in the architectural developments at Aswad. All phases display a marked architectural variability with only few rectangular buildings [81]. Oval buildings dominate throughout the sequence and the relocation of burials from residential structures to communal burial areas at the transition to the late PPNB highlights the distinct social organisation at Aswad, which returned to an emphasis on the community in their burial rituals rather than individual co-residential units. Importantly, a rectangular building (EA 6) in the last phase at Aswad contained two large storage basins, which yielded concentrations of barley and emmer grains [81,82]. The absence of chaff in these two basins shows that the grains were fully processed prior to storage-a potential sign for communal collaboration in post-harvest crop processing [50] — and the volume of the basins suggests a communal facility rather than household storage. The initial selection of non-shattering at Aswad may have been related to smaller co-resident groups, indicated by the association of burials with individual buildings during the early-middle PPNB. However, the low proportions of non-shattering spikelets throughout the sequence, reflective of very low selection rates, were then associated with a return to communal storage, which we already identified as a key indicator for mixing differently managed cereal subpopulations that experienced variable selection pressures.

\section{Discussion and Conclusions}

This model sees the emergence of increasingly independent households and the associated reorganisation of labour and sharing networks within early agricultural communities as central socio-economic factors that established the conditions for selection and the genetic fixation of domestication traits since the early and middle PPNB. I propose that these conditions were related to the reduced variability of management practices within the smaller household units, which genetically isolated individual cereal subpopulations and allowed the genetic fixation of traits in those populations that experienced sufficiently strong selection pressures. In contrast, the strong communal organisation of subsistence activities during the PPNA did demonstrably not establish conditions for selection. Seen through the lens of individual household units that increasingly restricted food sharing networks, this process introduced incentives and necessities to invest more energy, in the form of agricultural labour, into plant cultivation. First, the individual organisation of storage and distribution of the cultivated cereals would likely represent an incentive for 
households to invest more labour into their cultivation system, as they do not have to share the outputs $[44,52,53]$. Second, annual cultivation systems do not necessarily lead to higher yields than gathering but require higher labour inputs [138], indicating that the maintenance of a cultivation regime in which non-shattering cereal ears could be fixed was a comparatively labour-intensive endeavour. Third, individual storage means individual risk management and the associated need to produce a marginal surplus for coping with yield variability and spoilage losses $[55,125,139]$, confronting households with additional needs to assure continuous investments into crop cultivation systems. Taken together, these arguments further illustrate why the development of continuous cultivation systems in which domestication traits were selected in increasingly separated lineages and eventually fixed on a population level could only unfold once individual households gained sufficient control over the necessary stages of the cultivation, processing, storage, and distribution processes. These developments are reflected at, e.g., Cafer Höyük and Tell Qarassa, while communities at, e.g., Dja'de, Aşiklı Höyük, or Tell Aswad, where selection rates for nonshattering phenotypes were very low or close to zero, conserved a strong communal aspect in their food exploitation and distribution systems. On one hand, these communal strategies maintained constant geneflow between the exploited subpopulations that experienced different selection pressures but also reduced the incentives—and necessities-for high labour investments into annual cultivation regimes due to collective risk management. Increased selection rates were therefore a function of inherently social developments towards households as task-oriented economic units, presumably entangled with changing notions of ownership, food sharing practices, and the organisation of agricultural tasks. This model situates the agro-technological requirements for cereal domestication in its socio-economic context and helps to explain why management and storage systems that selected for the earliest non-shattering cereal populations evolved since the early-middle PPNB but not during the PPNA.

We must also note that the calculation of selection rates assumes a metapopulationwide process throughout the entire Fertile Crescent [140], or relatively large sub-regions such as the southern Levant [24], but cannot be based on individual selection chains towards non-shattering populations. However, some socio-economic settings did not produce strong selection pressures (e.g., at Dja'de, Aşiklı Höyük, Tell Aswad), which reduced selection rates on a metapopulation-level, so we must ask to which degree the calculation of supra-regional selection rates masks individual processes that we can observe archaeologically? One argument why local selection may have been much stronger than the supra-regional average is the early appearance of free-threshing wheats, which were already present during the early PPNB at Aşiklı Höyük [121] and at many middle PPNB sites throughout the Levant [119]. These early lineages of free-threshing wheats evolved when emmer wheat populations, from which they were derived, were still dominated by shattering spikelets. This highlights that the evolution of crops with additional domestication traits (here soft glumes) was underway long before exploited populations of their progenitors were fully non-shattering. Understanding evolutionary processes and domestication must therefore consider the local and site-specific conditions ( $c f$. Charles et al. [137]), which are the basis for the averaged rates of selection on a supra-regional level. A main conclusion from the socio-economic domestication model is that we need a "bottom-up" approach to understand co-evolutionary processes under domestication, based on an evaluation of the individual sites that yield proxy data for rates of selection. Only then can we contextualise and understand why selection rates changed, which in turn will benefit modelling of selection coefficients and genetic change under domestication.

By situating evolutionary change under domestication in its socio-economic context, I do not intend to imply that the discussed social and economic factors were more important than others for shaping the nature of selection, such as the genetic basis of phenotypic domestication traits, population-genetic constraints on selection, or the importance of livestock for building up resilient agricultural systems (a factor I have widely neglected in this model but which contributed to the intensified cultivation practices in the late 
PPNB) $[22,24,127,141]$. Domestication was long seen as a human-driven process with a focus on conscious selection and the gaining of control over plants and animals [142-145]. With a better understanding of underlying genetic processes, however, this focus on searching for factors that drive selection heavily shifted towards the non-human partners in domestication processes. This is understandable considering the century-long bias in domestication research and the associated research gaps, but it is increasingly difficult to understand patterns in domestication processes without a careful analysis of human behaviours [146]. Perhaps more than most fields of research, domestication studies suffer from this strong tendency to focus on "natural" or "cultural" agents. By associating genetic selection with changing socio-economic practices, the model presented here aims at further closing this artificial gap. Selection of traits like non-shattering cereal ears unfolded in arable environments that gradually developed with the emergence of social groups that pooled labour and resources, started to develop new storage and crop-handling systems, and restricted sharing-networks of cultivated food resources that must have been associated with new notions of ownership. These inherently social processes were based on the ecology of the exploited cereals but also affected their genetic structure. The responses of the cultivated cereal populations to the new agro-ecological conditions confronted the human partners with a changing composition of phenotypes, further affecting decisionmaking in emerging cultivation systems. Arguably, social relations and genetic selection are part of the same domestication process. The farming communities which evolved in this process should therefore be understood as a collective of human and non-human organisms that live in and from mutually beneficial collaborations [56]. From this follows that we must also understand its emergence as the evolution of a collective, shaped by ecological, social, economic, and genetic relationships that created the conditions under which all involved partners changed and continue to change.

Supplementary Materials: The following are available online at https:/ /www.mdpi.com/article/10.339 0/agronomy11122432/s1, Table S1. Dataset for non-shattering spikelets. Based on Allaby et al. (2017) and modified (see comments and Appendix A).

Funding: This research received funding from the Heinrich Böll Foundation (Doctoral Scholarship) and the European Commission (Marie Sklodowska-Curie Action, grant No. 838395).

Institutional Review Board Statement: Not applicable.

Informed Consent Statement: Not applicable.

Data Availability Statement: All data are included in the article or given in the Supplementary Information.

Acknowledgments: The first ideas for this piece of work emerged several years ago and developed through discussions with colleagues and feedback the author received during conference presentations. I would like to thank Amy Bogaard and Ian Kuijt for the inspiring discussions we had about the core ideas of this paper, long before any written draft was available. Their comments and criticism immensely helped to reconsider the original ideas. I am also thankful for the feedback I received at the annual meeting of the British Association of Near Eastern Archaeology (BANEA) in Oxford in January 2020 and the workshop "Re-evaluating the Origins and Trajectories of Domestication" in Santa Fe in March 2020.

Conflicts of Interest: The author declares no conflict of interest.

\section{Appendix A}

The dataset for non-shattering spikelets among PPN cereal chaff assemblages was taken from Allaby et al. [24]. Due to the challenges in separating wild-type and domestictype chaff, different analysts developed different approaches, which complicates comparability between assemblages. An example for this is the use of an intermediate category called "possibly domestic spikelets" by Tanno and Willcox [10,11], which most archaeobotanists did not use before. Allaby et al. counted the possibly domestic specimens as domestic types, which increased proportions of non-shattering spikelets in the assem- 
blages where this category was used. This induced a bias for the chaff assemblages from Tell Qaramel (Late Epipalaeolithic/PPNA), ZAD 2 (PPNA), and Nevalı Çorı (early PPNB), where proportions of non-shattering were reported to be as high as $22.2 \%, 28.9 \%$, and $31.5 \%$, respectively. However, in the original publications, the authors described all three chaff assemblages as not displaying any reliable evidence for selection towards non-shattering [10,11,97]. Somewhat confusing is Edwards' et al. [97] publication of the ZAD 2 data, as the barley chaff counts reported in their table did not match the chaff counts reported in the text, where "definite", "probable" and "dubious" identifications were reported. Based on their table, $28.9 \%$ of spikelets are of the non-shattering type but when only the "definite" identifications are used, domestic types contribute $11.1 \%$ to the assemblage. Likewise, when the "possibly domestic" identifications from Tell Qaramel and Nevalı Çorı are omitted, proportions for domestic types are as low as $0 \%$ and $4.4 \%$, respectively (Table S1). The high proportions used by Allaby et al. are therefore problematic and likely overestimate selection towards non-shattering. Based on these considerations, I have decided to omit any unsecure identifications, which slightly modified the dataset for non-shattering spikelets shown in Figure 2c. This also affected the proportions of non-shattering emmer spikelets from Seker al-Aheimar, which were reduced from $83.3 \%$ to $66.6 \%$. (now only based on three diagnostic specimens but all other specimens were classified as "possibly domestic" by Tanno and Willcox [11], so we can assume that this late PPNB assemblage reflects high proportions of non-shattering ears in the cultivated emmer populations).

\section{References}

1. Snir, A.; Nadel, D.; Groman-Yaroslavski, I.; Melamed, Y.; Sternberg, M.; Bar-Yosef, O.; Weiss, E. The Origin of Cultivation and Proto-Weeds, Long Before Neolithic Farming. PLoS ONE 2015, 10, e0131422. [CrossRef]

2. Maeda, O.; Lucas, L.; Silva, F.; Tanno, K.-I.; Fuller, D.Q. Narrowing the harvest: Increasing sickle investment and the rise of domesticated cereal agriculture in the Fertile Crescent. Quat. Sci. Rev. 2016, 145, 226-237. [CrossRef]

3. Weide, A.; Riehl, S.; Zeidi, M.; Conard, N.J. A systematic review of wild grass exploitation in relation to emerging cereal cultivation throughout the Epipalaeolithic and aceramic Neolithic of the Fertile Crescent. PLoS ONE 2018, 13, e0189811. [CrossRef]

4. Meadows, J. The earliest farmers? Archaeobotanical research at Pre-Pottery Neolithic A sites in Jordan. In Studies in the History and Archaeology of Jordan VIII: Archaeological and Historical Perspectives on Society, Culture and Identity; al-Khraysheh, F., Ed.; Department of Antiquities of Jordan: Amman, Jordan, 2004; pp. 119-128.

5. Willcox, G. Measuring grain size and identifying Near Eastern cereal domestication: Evidence from the Euphrates valley. J. Archaeol. Sci. 2004, 31, 145-150. [CrossRef]

6. Fuller, D.Q. Contrasting Patterns in Crop Domestication and Domestication Rates: Recent Archaeobotanical Insights from the Old World. Ann. Bot. 2007, 100, 903-924. [CrossRef] [PubMed]

7. White, C.E.; Makarewicz, C.A. Harvesting practices and early Neolithic barley cultivation at el-Hemmeh, Jordan. Veg. Hist. Archaeobot. 2012, 21, 85-94. [CrossRef]

8. Colledge, S.; Conolly, J.; Finlayson, B.; Kuijt, I. New insights on plant domestication, production intensification, and food storage: The archaeobotanical evidence from PPNA Dhra'. Levant 2018, 50, 14-31. [CrossRef]

9. Asouti, E. Human Palaeoecology in Southwest Asia During the Early Pre-Pottery Neolithic (c. 9700-8500 cal BC): The Plant Story. In Neolithic Corporate Identities. Studies in Early Near Eastern Production, Subsistence and Environment 20; Benz, M., Gebel, H.G.K., Watkins, T., Eds.; Ex Oriente: Berlin, Germany, 2017; pp. 21-53.

10. Tanno, K.-I.; Willcox, G. How Fast Was Wild Wheat Domesticated? Science 2006, 311, 1886. [CrossRef]

11. Tanno, K.-I.; Willcox, G. Distinguishing wild and domestic wheat and barley spikelets from early Holocene sites in the Near East. Veg. Hist. Archaeobot. 2012, 21, 107-115. [CrossRef]

12. Arranz-Otaegui, A.; Colledge, S.; Zapata, L.; Teira-Mayolini, L.C.; Ibáñez, J.J. Regional diversity on the timing for the initial appearance of cereal cultivation and domestication in southwest Asia. Proc. Natl. Acad. Sci. USA 2016, 113, 14001-14006. [CrossRef] [PubMed]

13. Fuller, D.Q.; Denham, T.; Arroyo-Kalin, M.; Lucas, L.; Stevens, C.J.; Qin, L.; Allaby, R.G.; Purugganan, M.D. Convergent evolution and parallelism in plant domestication revealed by an expanding archaeological record. Proc. Natl. Acad. Sci. USA 2014, 111, 6147-6152. [CrossRef] [PubMed]

14. Hillman, G.C.; Davies, M.S. Measured Domestication Rates in Wild Wheats and Barley Under Primitive Cultivation, and Their Archaeological Implications. J. World Prehist. 1990, 4, 157-222. [CrossRef]

15. Kuijt, I.; Goring-Morris, N. Foraging, Farming, and Social Complexity in the Pre-Pottery Neolithic of the Southern Levant: A Review and Synthesis. J. World Prehist. 2002, 16, 361-440. [CrossRef] 
16. Ex Oriente. PPND—The Platform for Neolithic Radiocarbon Dates. Available online: http://www.exoriente.org/associated_ projects/ppnd.php (accessed on 19 October 2021).

17. Purugganan, M.D.; Fuller, D.Q. The nature of selection during plant domestication. Nature 2009, 457, 843-848. [CrossRef] [PubMed]

18. Purugganan, M.D.; Fuller, D.Q. Archaeological data reveal slow rates of evolution during plant domestication. Evolution 2011, 65, 171-183. [CrossRef] [PubMed]

19. Kislev, M.E.; Weiss, E.; Hartmann, A. Impetus for sowing and the beginning of agriculture: Ground collecting of Wild Cereals. Proc. Natl. Acad. Sci. USA 2004, 101, 2692-2695. [CrossRef] [PubMed]

20. Ibáñez, J.J.; Anderson, P.C.; González-Urquijo, J.; Gibaja, J. Cereal cultivation and domestication as shown by microtexture analysis of sickle gloss through confocal microscopy. J. Archaeol. Sci. 2016, 73, 62-81. [CrossRef]

21. Allaby, R.G.; Kitchen, J.L.; Fuller, R.Q. Surprisingly Low Limits of Selection in Plant Domestication. Evol. Bioinform. 2015, 11s2, EBO-S33495. [CrossRef]

22. Avni, R.; Nave, M.; Barad, O.; Baruch, K.; Twardziok, S.O.; Gundlach, H.; Hale, I.; Mascher, M.; Spannagl, M.; Wiebe, K.; et al Wild emmer genome architecture and diversity elucidate wheat evolution and domestication. Science 2017, 357, 93-97. [CrossRef] [PubMed]

23. Allaby, R. Integrating the processes in the evolutionary system of domestication. J. Exp. Bot. 2010, 61, 935-944. [CrossRef] [PubMed]

24. Allaby, R.G.; Stevens, C.; Lucas, L.; Maeda, O.; Fuller, D.Q. Geographic mosaics and changing rates of cereal domestication. Philos. Trans. R. Soc. B Biol. Sci. 2017, 372, 20160429. [CrossRef] [PubMed]

25. Fuller, D.Q.; Allaby, R.G.; Stevens, C. Domestication as innovation: The entanglement of techniques, technology and chance in the domestication of cereal crops. World Archaeol. 2010, 42, 13-28. [CrossRef]

26. Asouti, E.; Fuller, D.Q. A Contextual Approach to the Emergence of Agriculture in Southwest Asia: Reconstructing Early Neolithic Plant-Food Production. Curr. Anthropol. 2013, 54, 299-345. [CrossRef]

27. Byrd, B.F. Public and Private, Domestic and Corporate: The Emergence of the Southwest Asian Village. Am. Antiq. 1994, 59, 639-666. [CrossRef]

28. Bar-Yosef, O.; Meadow, R.H. The origins of agriculture in the Near East. In Last Hunters, First Farmers: New Perspectives on the Prehistoric Transition to Agriculture; Price, T.D., Gebauer, A.-B., Eds.; School of American Research Press: Santa Fe, NM, USA, 1995; pp. 39-94.

29. Rollefson, G.O. Changes in architecture and social organization at 'Ain Ghazal. In The Prehistory of Jordan II, Perspectives from 1997; Gebel, H.G.K., Kafifi, Z., Rollefson, G.O., Eds.; Ex Oriente: Berlin, Germany, 1997; pp. 287-307.

30. Wright, K.I. The Social Origins of Cooking and Dining in Early Villages of Western Asia. Proc. Prehist. Soc. 2000, 66, 89-121. [CrossRef]

31. Flannery, K.V. The Origins of the Village Revisited: From Nuclear to Extended Households. Am. Antiq. 2002, 67, 417-433. [CrossRef]

32. Banning, E.B. Housing neolithic farmers. Near East. Archaeol. 2003, 66, 4-21. [CrossRef]

33. Kuijt, I. Demography and Storage Systems During the Southern Levantine Neolithic Demographic Transition. In The Neolithic Demographic Transition and Its Consequences; Bocquet-Appel, J.-P., Bar-Yosef, O., Eds.; Springer: Dordrecht, The Netherlands, 2008; pp. 287-313.

34. Bogaard, A.; Charles, M.; Twiss, K.C.; Fairbairn, A.; Yalman, N.; Filipović, D.; Demirergi, G.A.; Ertuğ, F.; Russell, N.; Henecke, J. Private pantries and celebrated surplus: Storing and sharing food at Neolithic Çatalhöyük, Central Anatolia. Antiquity 2009, 83, 649-668. [CrossRef]

35. Kuijt, I.; Guerrero, E.; Molist, M.; Anfruns, J. The changing Neolithic household: Household autonomy and social segmentation, Tell Halula, Syria. J. Anthropol. Archaeol. 2011, 30, 502-522. [CrossRef]

36. Atakuman, Ç. Architectural Discourse and Social Transformation During the Early Neolithic of Southeast Anatolia. J. World Prehist. 2014, 27, 1-42. [CrossRef]

37. Wilk, R.R.; Rathje, W.L. Household Archaeology. Am. Behav. Sci. 1982, 25, 617-639. [CrossRef]

38. Hendon, J.A. Archaeological Approaches to the Organization of Domestic Labor: Household Practice and Domestic Relations. Annu. Rev. Anthropol. 1996, 25, 45-61. [CrossRef]

39. Smith, M.E. Household possessions and wealth in agrarian states: Implications for archaeology. J. Anthropol. Archaeol. 1987, 6, 297-335. [CrossRef]

40. Byrd, B.F. Households in Transition Neolithic Social Organization within Southwest Asia. In Life in Neolithic Farming Communities. Social Organization, Identity, and Differentiation; Kuijt, I., Ed.; Kluwer Academic Publishers: New York, NY, USA, 2000 ; pp. 63-102.

41. Hendon, J.A. Living and working at home: The social archaeology of household production and social relations. In A Companion to Social Archaeology; Meskell, L., Preucel, R., Eds.; Blackwell Publishing: Oxford, UK, 2004; pp. 272-286.

42. Duru, G.; Özbaşaran, M.; Yelözer, S.; Uzdurum, M.; Kuijt, I. Space making and home making in the world's first villages: Reconsidering the circular to rectangular architectural transition in the Central Anatolian Neolithic. J. Anthropol. Archaeol. 2021, 64, 101357. [CrossRef]

43. Kuijt, I. Material Geographies of House Societies: Reconsidering Neolithic Çatalhöyük, Turkey. Camb. Archaeol. J. 2018, 28, 565-590. [CrossRef] 
44. Flannery, K.V. The origins of the village as a settlement type in Mesoamerica and the Near East: A comparative study. In Man, Settlement and Urbanism; Ucko, P.J., Tringham, R., Dimbleby, G.W., Eds.; Duckworth: London, UK, 1972; pp. $23-53$.

45. Bar-Yosef, O. From sedentary foragers to village hierarchies: The emergence of social institutions. In The Origin of Human Social Institutions; Runciman, W.G., Ed.; Oxford University Press: Oxford, UK, 2001; pp. 1-38.

46. Goring-Morris, A.N.; Belfer-Cohen, A. A Roof Over One's Head: Developments in Near Eastern Residential Architecture Across the Epipalaeolithic-Neolithic Transition. In The Neolithic Demographic Transition and Its Consequences; Bocquet-Appel, J.-P., Bar-Yosef, O., Eds.; Springer: Dordrecht, The Netherlands, 2008; pp. 239-286.

47. Yaka, R.; Mapelli, I.; Kaptan, D.; Doğu, A.; Chyleński, M.; Erdal, Ö.D.; Koptekin, D.; Vural, K.B.; Bayliss, A.; Mazzucato, C.; et al. Variable kinship patterns in Neolithic Anatolia revealed by ancient genomes. Curr. Biol. 2021, 31, 2455-2468.e18. [CrossRef] [PubMed]

48. Kuijt, I. Place, Death, and the Transmission of Social Memory in Early Agricultural Communities of the Near Eastern Pre-Pottery Neolithic. Archeol. Pap. Am. Anthropol. Assoc. 2001, 10, 80-99. [CrossRef]

49. Kuijt, I. Home is where we keep our food: The origins of agriculture and late pre-pottery Neolithic food storage. Paléorient 2011, 37, 137-152. [CrossRef]

50. Bogaard, A. Neolithic "cooperatives": Assessing supra-household cooperation in crop production at Çatalhöyük and beyond. In Neolithic Corporate Identities. Studies in Early Near Eastern Production, Subsistence and Environment 20; Benz, M., Gebel, H.G.K., Watkins, T., Eds.; Ex Oriente: Berlin, Germany, 2017; pp. 119-133.

51. Bowles, S.; Choi, J.-K. Coevolution of farming and private property during the early Holocene. Proc. Natl. Acad. Sci. USA 2013, 110, 8830-8835. [CrossRef] [PubMed]

52. Bowles, S.; Choi, J.-K. The Neolithic Agricultural Revolution and the Origins of Private Property. J. Political Econ. 2019, 127, 2186-2228. [CrossRef]

53. Woodburn, J. Egalitarian Societies. Man 1982, 17, 431-451. [CrossRef]

54. Benz, M. Die Neolithisierung im Vorderen Orient: Theorien, archäologische Daten und ein ethnologisches Modell. In Studies in Early Near Eastern Production, Subsistence and Environment 7; Ex Oriente: Berlin, Germany, 2000.

55. Kuijt, I. The Neolithic refrigerator on a Friday night: How many people are coming to dinner and just what should I do with the slimy veggies in the back of the fridge? Environ. Archaeol. 2015, 20, 321-336. [CrossRef]

56. Bogaard, A.; Allaby, R.G.; Arbuckle, B.S.; Bendrey, R.; Crowley, S.; Cucchi, T.; Denham, T.; Frantz, L.; Fuller, D.Q.; Gilbert, T.; et al. Reconsidering domestication from a process archaeology perspective. World Archaeol. 2021. [CrossRef]

57. Rosenberg, M.; Erim-Özdoğan, A. The Neolithic in southeastern Anatolia. In The Oxford Handbook of Ancient Anatolia; Steadman, S.R., McMahon, G., Eds.; Oxford University Press: Oxford, UK, 2011.

58. Erim-Özdoğan, A. Çayönü. In The Neolithic in Turkey: The Tigris Basin; Özdoğan, M., Başgelen, N., Kuniholm, P.I., Eds.; Archaeology and Art Publications: Istanbul, Turkey, 2011; pp. 185-269.

59. Rosenberg, M.; Redding, R.W. Hallan Çemi and early village organization in eastern Anatolia. In Life in Neolithic Farming Communities. Social Organization, Identity, and Differentiation; Kuijt, I., Ed.; Kluwer Academic Publishers: New York, NY, USA, 2000; pp. 39-62.

60. Kuijt, I. What Do We Really Know about Food Storage, Surplus, and Feasting in Preagricultural Communities? Curr. Anthropol. 2009, 50, 641-644. [CrossRef] [PubMed]

61. Stordeur, D. Le village de Jerf el Ahmar (Syrie, 9500-8700 av. J.-C.): L'architecture, Miroir d'une Société néolithique Complexe; CNRS Éditions: Paris, France, 2015.

62. Willcox, G.; Stordeur, D. Large-scale cereal processing before domestication during the tenth millennium cal BC in northern Syria. Antiquity 2012, 86, 99-114. [CrossRef]

63. Stordeur, D. New discoveries in architecture and symbolism at Jerf el Ahmar (Syria), 1997-1999. Neo-Lithics 2000, 1, 1-4.

64. Willcox, G. Charred plant remains from a 10th millennium B.P. kitchen at Jerf el Ahmar (Syria). Veg. Hist. Archaeobot. 2002, 11, 55-60. [CrossRef]

65. Stordeur, D.; Brenet, M.; der Aprahamian, G.; Roux, J.-C. Les batiments communautaires de Jerf el Ahmar et Mureybet horizon PPNA (Syrie). Paléorient 2001, 26, 29-44. [CrossRef]

66. Yartah, T. Les bâtiments communautaires de Tell'Abr 3 (PPNA, Syrie). Neo-Lithics 2005, 1, 3-9.

67. Willcox, G.; Fornite, S.; Herveux, L. Early Holocene cultivation before domestication in northern Syria. Veg. Hist. Archaeobot. 2008, 17, 313-325. [CrossRef]

68. Cauvin, J.; Aurenche, O.; Cauvin, M.-C.; Balkan-Atli, N. The Pre-Pottery Site of Cafer Höyük. In The Neolithic in Turkey: The Euphrates Basin; Özdoğan, M., Başgelen, N., Kuniholm, P.I., Eds.; Arkeoloji ve Sanat Yayınları: Istanbul, Turkey, $2011 ;$ pp. 1-40.

69. Guerrero, E.; Molist, M.; Kuijt, I.; Anfruns, J. Seated memory: New insights into Near Eastern Neolithic mortuary variability from Tell Halula, Syria. Curr. Anthropol. 2009, 50, 379-391. [CrossRef]

70. Arranz-Otaegui, A.; Colledge, S.; Ibañez, J.J.; Zapata, L. Crop husbandry activities and wild plant gathering, use and consumption at the EPPNB Tell Qarassa North (South Syria). Veg. Hist. Archaeobot. 2016, 25, 629-645. [CrossRef]

71. van Zeist, W.; de Roller, G.J. The plant husbandry of aceramic Çayönü, SE Turkey. Palaeohistoria 1994, 1991/1992, 65-96.

72. Molist, M. Espace collectif et espace domestique dans le Néolithique des IXeme et VIIIeme millénaires BP au nord de la Syrie: Apports du site de Tell Halula (valleé de l'Euphrate). MOM Éditions 1998, 28, 115-130. 
73. Kenyon, K. Excavations at Jericho. Vol. III: The Architecture and Stratigraphy of the Tell; British School of Archaeology in Jerusalem: London, UK, 1981.

74. Bar-Yosef, O.; Gopher, A. The Excavations of Netiv Hagdud. Stratigraphy and Architectural Remains. In An Early Neolithic Village in the Jordan Valley; Bar-Yosef, O., Gopher, A., Eds.; Peabody Museum of Archaeology and Ethnology, Harvard University: Cambridge, MA, USA, 1997; pp. 41-69.

75. Kuijt, I.; Finlayson, B. Evidence for food storage and predomestication granaries 11,000 years ago in the Jordan Valley. Proc. Natl. Acad. Sci. USA 2009, 106, 10966-10970. [CrossRef] [PubMed]

76. Weiss, E.; Kislev, M.E.; Hartmann, A. Autonomous Cultivation Before Domestication. Science 2006, 312, 1608-1610. [CrossRef]

77. Kislev, M.E.; Hartmann, A.; Noy, T. The vegetal subsistence of Gilgal I as reflected in the assemblage of locus 11. In Gilgal: Excavations at Early Neolithic Sites in the Lower Jordan Valley. The Excavations of Tamar Noy; Bar-Yosef, O., Goring-Morris, A.N., Gopher, A., Eds.; Oxbow Books: Oxford, UK; Oakville, ON, Canada, 2010; pp. 251-257.

78. Byrd, B.F. Early village Life at Beidha, Jordan: Neolithic Spatial Organization and Vernacular Architecture; Oxford University Press: Oxford, UK, 2005.

79. Rollefson, G.O.; Simmons, A.H. The Neolithic village of 'Ain Ghazal, Jordan: Preliminary report on the 1984 season. Bull. Am. Sch. Orient. Res. Suppl. 1986, 24, 145-164.

80. Garfinkel, Y. Yiftahel: A Neolithic Village from the Seventh Millennium B.C. in Lower Galilee, Israel. J. Field Archaeol. 1987, 14, 199-212. [CrossRef]

81. Stordeur, D.; Helmer, D.; Jamous, B.; Khawam, R.; Molist, M.; Willcox, G. Le PPNB de Syrie du Sud à travers les découvertes récentes à tell Aswad. In Hauran V La Syrie Du Sud Du Néolithique À L'antiquité Tardive Recherches Récentes Actes Du Colloque De Damas 2007; Presses de l'Ifpo: Beirut, Lebanon, 2010; pp. 41-68.

82. Douché, C.; Willcox, G. New archaeobotanical data from the Early Neolithic sites of Dja'de el-Mughara and Tell Aswad (Syria): A comparison between the Northern and the Southern Levant. Paléorient 2018, 44, 45-58.

83. Mahasneh, H.M.; Bienert, H.-D. Unfolding the Earliest Pages of Sedentism: The Pre-Pottery Neolithic Settlement of Es-Sifiya in Southern Jordan. In At the Crossroads: Essays on the Archaeology, History and Current Affairs of the Middle East; Bienert, H.-D., Müller-Neuhof, B., Eds.; German Protestant Institute of Archaeology in Amman: Amman, Jordan, 2000; pp. 1-14.

84. Nissen, H.J.; Muheisen, M.; Gebel, H.-G.K. Report on the first two seasons of excavations at Basta (1986-1987). Annu. Dep. Antiq. Jordan 1987, 31, 79-119.

85. Gebel, H.G.K.; Bienert, H.-D.; Krämer, T.; Müller-Neuhof, B.; Neef, R.; Timm, J.; Wright, K. Ba'ja hidden in the Petra mountains: Preliminary report on the 1997 excavations. In The Prehistory of Jordan II. Perspectives from 1997; Gebel, H.G.K., Kafafi, Z., Rollefson, G.O., Eds.; Ex oriente: Berlin, Germany, 1997; pp. 221-262.

86. Bar-Yosef, O. The Walls of Jericho: An Alternative Interpretation. Curr. Anthropol. 1986, 27, 157-162. [CrossRef]

87. Kuijt, I. Negotiating Equality through Ritual: A Consideration of Late Natufian and Prepottery Neolithic A Period Mortuary Practices. J. Anthropol. Archaeol. 1996, 15, 313-336. [CrossRef]

88. Mithen, S.J.; Finlayson, B.; Smith, S.; Jenkins, E.; Najjar, M.; Maričević, D. An 11,600-year-old communal structure from the Neolithic of southern Jordan. Antiquity 2011, 85, 350-364. [CrossRef]

89. Schmidt, K. Gobekli Tepe-the Stone Age Sanctuaries. Doc. Praehist. 2010, 37, 239-256. [CrossRef]

90. Finlayson, B.; Mithen, S.J.; Najjar, M.; Smith, S.; Maričević, D.; Pankhurst, N.; Yeomans, L. Architecture, sedentism, and social complexity at Pre-Pottery Neolithic A WF16, Southern Jordan. Proc. Natl. Acad. Sci. USA 2011, 108, 8183-8188. [CrossRef]

91. Ingold, T. The Significance of Storage in Hunting Societies. Man 1983, 18, 553-571. [CrossRef]

92. Benz, M. The principle of sharing: An introduction. In The Principle of Sharing. Segregation and Construction of Social Identities at the Transition from Foraging to Farming; Benz, M., Ed.; Ex Oriente: Berlin, Germany, 2010; pp. 1-18.

93. Finlayson, B. Egalitarian societies and the earliest Neolithic of Southwest Asia. Prehist. Archaeol. J. Interdiscip. Stud. 2020, 3, 27-43. [CrossRef]

94. Fuller, D.Q.; Willcox, G.; Allaby, R.G. Early agricultural pathways: Moving outside the 'core area' hypothesis in Southwest Asia. J. Exp. Bot. 2012, 63, 617-633. [CrossRef] [PubMed]

95. Willcox, G. Searching for the origins of arable weeds in the Near East. Veg. Hist. Archaeobot. 2012, 21, 163-167. [CrossRef]

96. Ibáñez, J.J.J.; Anderson, P.C.; Arranz-Otaegui, A.; González-Urquijo, J.E.; Lindahl, A.J.; Mazzucco, N.; Pichon, F.; Richter, T. Sickle Gloss Texture Analysis Elucidates Long-Term Evolution of Plant Harvesting During the Transition to Agriculture. J. Acrhaeological Sci. 2021, 136, 105502. [CrossRef]

97. Edwards, P.C.; Meadows, J.; Sayej, G.; Westaway, M. From the PPNA to the PPNB: New views from the Southern Levant after excavations at Zahrat adh-Dhra' 2 in Jordan. Paléorient 2004, 30, 21-60. [CrossRef]

98. Melamed, Y.; Plitmann, U.; Kislev, M.E. Vicia peregrina: An edible early Neolithic legume. Veg. Hist. Archaeobot. 2008, 17, 29-34. [CrossRef]

99. Colledge, S. Identifying pre-domestication cultivation in the archaeobotanical record using multivariate analysis. In The Origins of Agriculture and Crop Domestication; Damania, A.B., Valkoun, J., Willcox, G., Qualset, C.O., Eds.; ICARDA: Aleppo, Syria, 1998; pp. 121-131.

100. Hillman, G.C.; Hedges, R.; Moore, A.M.T.; Colledge, S.; Pettitt, P. New evidence of Lateglacial cereal cultivation at Abu Hureyra on the Euphrates. Holocene 2001, 11, 383-393. [CrossRef]

101. Colledge, S. Plant Exploitation on Epipalaeolithic and Early Neolithic Sites in the Levant; BAR Publishing: Oxford, UK, 2001. 
102. Jones, G. Weed phytosociology and crop husbandry: Identifying a contrast between ancient and modern practice. Rev. Palaeobot. Palynol. 1992, 73, 133-143. [CrossRef]

103. Bogaard, A.; Ater, M.; Hodgson, J.G. Arable weeds as a case study in plant-human relationships beyond domestication. In Hybrid Communities; Stépanoff, C., Vigne, J.-D., Eds.; Routledge: London, UK, 2018; pp. 97-112.

104. Jones, G.; Bogaard, A.; Charles, M.; Hodgson, J.G. Distinguishing the Effects of Agricultural Practices Relating to Fertility and Disturbance: A Functional Ecological Approach in Archaeobotany. J. Archaeol. Sci. 2000, 27, 1073-1084. [CrossRef]

105. Harris, D.R.; Fuller, D.Q. Agriculture: Definition and overview. In Encyclopedia of Global Archaeology; Smith, C., Ed.; Springer: New York, NY, USA, 2014; pp. 104-113.

106. Preece, C.; Jones, G.; Rees, M.; Osborne, C.P. Fertile Crescent crop progenitors gained a competitive advantage from large seedlings. Ecol. Evol. 2021, 11, 3300-3312. [CrossRef] [PubMed]

107. Blumler, M.A. Changing paradigms, wild cereal ecology, and agricultural origins. In The Dawn of Farming in the Near East. Studies in Early Near Eastern Production, Subsistence, and Environment 6; Cappers, R.T.J., Bottema, S., Eds.; Ex Oriente: Berlin, Germany, 2002; pp. 95-112.

108. Weide, A.; Hodgson, J.G.; Leschner, H.; Dovrat, G.; Whitlam, J.; Manela, N.; Melamed, Y.; Osem, Y.; Bogaard, A. The Association of Arable Weeds with Modern Wild Cereal Habitats: Implications for Reconstructing the Origins of Plant Cultivation in the Levant. Environ. Archaeol. 2021, 1-16. [CrossRef]

109. Hillman, G.C.; Colledge, S.M.; Harris, D.R. Plant-food economy during the Epipalaeolithic period at Tell Abu Hureyra, Syria: Dietary diversity, seasonality, and modes of exploitation. In Foraging and Farming: The Evolution of Plant Exploitation; Hillman, G.C., Harris, D.R., Eds.; Unwin Hyman: London, UK, 1989.

110. Abbo, S.; Lev-Yadun, S.; Gopher, A. Plant Domestication and Crop Evolution in the Near East: On Events and Processes. Crit. Rev. Plant Sci. 2012, 31, 241-257. [CrossRef]

111. Smith, B.D. Low-Level Food Production. J. Archaeol. Res. 2001, 9, 1-43. [CrossRef]

112. Svizzero, S. Plant domestication more rapid under optimizing behavior. J. Bioecon. 2018, 20, 287-308. [CrossRef]

113. Harlan, J.R. Harvesting of wild-grass seed and implications for domestication. In Prehistory of Agriculture: New Experimental and Ethnographic Approaches; Anderson, P.C., Ed.; University of California: Los Angeles, CA, USA, 1999; pp. 1-5.

114. Coqueugniot, E. Dja'de el Mughara (moyen-euphrate), un village néolithique dans son environnement naturel à la veille de la domestication. In Espace Naturel, Espace Habité en Syrie du Nord (10e-2e Millénaires av. J.-C.); Fortin, M., Aurenche, O., Eds.; Maison de l'Orient et de la Méditerranée Jean Pouilloux: Lyon, France, 1998; pp. 109-114.

115. Testart, A. The Significance of Food Storage Among Hunter-Gatherers: Residence Patterns, Population Densities, and Social Inequalities. Curr. Anthropol. 1982, 23, 523-537. [CrossRef]

116. Kislev, M.E. Pre-domesticated cereals in the Pre-Pottery Neolithic A period. In People and Culture in Change; Hershkovitz, I., Ed.; BAR Publishing: Oxford, UK, 1989; pp. 147-151.

117. Weide, A.; Riehl, S.; Zeidi, M.; Conard, N.J. Using new morphological criteria to identify domesticated emmer wheat at the aceramic Neolithic site of Chogha Golan (Iran). J. Archaeol. Sci. 2015, 57, 109-118. [CrossRef]

118. Pasternak, R. Investigations of botanical remains from Nevali Cori PPNB, Turkey: A short interim report. In Origin of Agricultural and Crop Domestication; Damania, A., Valkoum, J., Willcox, G., Quallset, C., Eds.; ICARDA: Aleppo, Syria, 1998 ; pp. $170-177$.

119. Nesbitt, M. When and where did domesticated cereals first occur in southwest Asia? In The Dawn of Farming in the Near East; Cappers, R., Bottema, S., Eds.; Ex Oriente: Berlin, Germany, 2002; pp. 113-132.

120. De Moulins, D. Agricultural Changes at Euphrates and Steppe Sites in the Mid-8th to the 6th Millenium BC; BAR Publishing: Oxford, UK, 1997.

121. Ergun, M.; Tengberg, M.; Willcox, G.; Douché, C. Plants of Aşıklı Höyük and changes through time: First archaeobotanical results from the 2010-14 excavation seasons. In The Early Settlement of Aşıkl Höyük: Essays in Honor of Ufuk Esin; Ege Yayinlari: Istanbul, Turkey, 2018; pp. 191-217.

122. Esin, U.; Harmankaya, S.; Aşıklı, H. Anadolu'da Uygarlı̆̆ın Doğuşu Avrupaya Yayılımı Türkiye'de Neolitik Dönem, Yeni Kazılar, Yeni Bulgular; Özdoğan, M., Başgelen, N., Eds.; Arkeoloji ve Sanat Yayınları: Istanbul, Turkey, 2007; pp. $255-272$.

123. Uzdurum, M. Live Together Around Fire: Hearths and the Use of Space at the Onset of Sedentism, Aşıklı Höyük (Turkey), a Case Study. In From the Caucasus to the Arabian Peninsula: Domestic Spaces in the Neolithic; Douché, C., Pichon, F., Eds.; Actes Du Colloque International: Bruxelles, Belgium, 2018; pp. 11-49.

124. Düring, B.S.; Marciniak, A. Households and communities in the central Anatolian Neolithic. Archaeol. Dialogues 2005, 12, 165-187. [CrossRef]

125. Forbes, H.; Foxhall, L. Ethnoarchaeology and storage in the ancient Mediterranean: Beyond risk and survival. In Food in Antiquity; Wilkins, J., Harvey, D., Dobson, M., Eds.; University of Exeter Press: Exeter, UK, 1995; pp. 69-86.

126. Jones, G.; Bogaard, A.; Halstead, P.; Charles, M.; Smith, H. Identifying the Intensity of Crop Husbandry Practices on the Basis of Weed Floras. Annu. Br. Sch. Athens 1999, 94, 167-189. [CrossRef]

127. Bogaard, A.; Isaakidou, V. From mega-sites to farmsteads: Community size, ideology and the nature of early farming landscapes in Western Asia and Europe. In Landscapes in Transition: Understanding Hunter-Gatherer and Farming Landscapes in the Early Holocene of Europe and the Levant; Finlayson, B., Warren, G., Eds.; Oxbow Books: Oxford, UK, 2010; pp. 192-207.

128. Kuijt, I. The Regeneration of Life: Neolithic Structures of Symbolic Remembering and Forgetting. Curr. Anthropol. 2008, 49, 171-197. [CrossRef] 
129. Christakis, K.S. Pithoi and food storage in Neopalatial Crete: A domestic perspective. World Archaeol. 1999, 31, 1-20. [CrossRef]

130. Hill, R.; Lacey, J.; Reynolds, P. Storage of barley grain in Iron Age type underground pits. J. Stored Prod. Res. 1983, 19, 163-171. [CrossRef]

131. Fenton, A. Grain storage in pits: Experiment and fact. In From the Stone Age to the 'Forty-Five; O'Connor, A., Clarke, D.V., Eds.; John Donald Pub. Ltd.: Edinburgh, UK, 1983; pp. 567-588.

132. Abdalla, A.E.-T.; Stigter, C.J.; Mohamed, H.A.; Mohammed, A.E.-T.; Gough, M.C. Effects of wall linings on moisture ingress into traditional grain storage pits. Int. J. Biometeorol. 2001, 45, 75-80. [CrossRef]

133. Akkermans, P.A.; Boerma, J.A.K.; Clason, A.T.; Hill, S.G.; Lohof, E.; Meiklejohn, C.; le Mière, M.; Molgat, G.M.F.; Roodenberg, J.J.; Rooyen, W.W.-V.; et al. Bouqras Revisited: Preliminary Report on a Project in Eastern Syria. Proc. Prehist. Soc. 1983, 49, 335-372. [CrossRef]

134. Schirmer, W. Some aspects of building at the 'aceramic-neolithic' settlement of Çayönü Tepesi. World Archaeol. 1990, 21, 363-387. [CrossRef]

135. van Zeist, W.; Waterbolk-Van Rooijen, W. The Palaeobotany of Tell Bouqras, eastern Syria. Paléorient 1985, 11, 131-147. [CrossRef]

136. Portillo, M.; Kadowaki, S.; Nishiaki, Y.; Albert, R.M. Early Neolithic household behavior at Tell Seker al-Aheimar (Upper Khabur, Syria): A comparison to ethnoarchaeological study of phytoliths and dung spherulites. J. Archaeol. Sci. 2014, 42, 107-118. [CrossRef]

137. Charles, M.; Fuller, D.Q.; Roushannafas, T.; Bogaard, A. An assessment of crop plant domestication traits at Çatalhöyük. In Humans and Environments of Çatalhöyük: Reports from the 2009-2017 Seasons; Hodder, I., Ed.; British Institute at Ankara: London, UK, 2021; pp. 125-136.

138. Bowles, S. Cultivation of cereals by the first farmers was not more productive than foraging. Proc. Natl. Acad. Sci. USA 2011, 108, 4760-4765. [CrossRef]

139. Halstead, P. The economy has a normal surplus: Economic stability and social change among early farming communities of Thessaly, Greece. In Bad Year Economics: Cultural Responses to Risk and Uncertainty; Halstead, P., O'Shea, J., Eds.; Cambridge University Press: Cambridge, UK, 1989; pp. 68-80.

140. Fuller, D.Q.; Asouti, E.; Purugganan, M.D. Cultivation as slow evolutionary entanglement: Comparative data on rate and sequence of domestication. Veg. Hist. Archaeobot. 2012, 21, 131-145. [CrossRef]

141. Bogaard, A. 'Garden agriculture' and the nature of early farming in Europe and the Near East. World Archaeol. 2005, 37, 177-196. [CrossRef]

142. Bökönyi, S. Definitions of animal domestication. In The Walking Larder. Patterns of Domestication, Pastoralism, and Predation; Clutton-Brock, J., Ed.; Unwin: Cambridge, UK, 1989; pp. 1-4.

143. Ducos, P. Defining domestication: A clarification. In The Walking Larder. Patterns of Domestication, Pastoralism, and Predation; Clutton-Brock, J., Ed.; Unwin: Cambridge, UK, 1989; pp. 28-30.

144. Abbo, S.; Gopher, A. Near Eastern Plant Domestication: A History of Thought. Trends Plant Sci. 2017, 22, 491-511. [CrossRef] [PubMed]

145. Abbo, S.; Lev-Yadun, S.; Gopher, A. The 'Human Mind' as a common denominator in plant domestication. J. Exp. Bot. 2014, 65, 1917-1920. [CrossRef]

146. Brown, T.A. The Role of Humans in a Protracted Transition from Hunting-Gathering to Plant Domestication in the Fertile Crescent. Front. Plant Sci. 2018, 9, 1287. [CrossRef] [PubMed] 